\title{
Review Article \\ Exercise Induced Adipokine Changes and the Metabolic Syndrome
}

\author{
Saeid Golbidi and Ismail Laher \\ Department of Pharmacology and Therapeutics, Faculty of Medicine, University of British Columbia, \\ Vancouver, BC, Canada V6T 1Z3 \\ Correspondence should be addressed to Ismail Laher; ilaher@mail.ubc.ca
}

Received 25 July 2013; Accepted 18 October 2013; Published 19 January 2014

Academic Editor: Caroline J. Magri

Copyright (C) 2014 S. Golbidi and I. Laher. This is an open access article distributed under the Creative Commons Attribution License, which permits unrestricted use, distribution, and reproduction in any medium, provided the original work is properly cited.

\begin{abstract}
The lack of adequate physical activity and obesity created a worldwide pandemic. Obesity is characterized by the deposition of adipose tissue in various parts of the body; it is now evident that adipose tissue also acts as an endocrine organ capable of secreting many cytokines that are though to be involved in the pathophysiology of obesity, insulin resistance, and metabolic syndrome. Adipokines, or adipose tissue-derived proteins, play a pivotal role in this scenario. Increased secretion of proinflammatory adipokines leads to a chronic inflammatory state that is accompanied by insulin resistance and glucose intolerance. Lifestyle change in terms of increased physical activity and exercise is the best nonpharmacological treatment for obesity since these can reduce insulin resistance, counteract the inflammatory state, and improve the lipid profile. There is growing evidence that exercise exerts its beneficial effects partly through alterations in the adipokine profile; that is, exercise increases secretion of anti-inflammatory adipokines and reduces proinflammatory cytokines. In this paper we briefly describe the pathophysiologic role of four important adipokines (adiponectin, leptin, TNF- $\alpha$, and IL-6) in the metabolic syndrome and review some of the clinical trials that monitored these adipokines as a clinical outcome before and after exercise.
\end{abstract}

\section{Introduction}

The metabolic syndrome refers to a group of symptoms including obesity, high blood pressure, insulin resistance, and hyperlipidemia, in which the role of central obesity is critical $[1,2]$. The increased prevalence of obesity in both industrialized and developing countries is associated with a surge in the preponderance of metabolic syndrome. In North America, $55 \%$ of 97 million adults are either overweight or obese (with a body mass index (BMI) $\geq 25$ ) [3]. In a study of 12363 US men and women using the National Cholesterol Education Program Adult Treatment Panel III guidelines, the metabolic syndrome was diagnosed in $22.8 \%$ and $22.6 \%$ of the men and women, respectively [4]. The metabolic syndrome can be present in different forms, according to the combination of the various components of the syndrome, and it is well established that the metabolic syndrome increases the risk for the development of cardiovascular disease, type II diabetes, and cancer [5-7]. It is not yet known how the metabolic syndrome is triggered or how the different components are causally linked, but insulin resistance is strongly suspected as a common pathophysiologic link $[8,9]$. It is clear that there is a positive correlation between body weight and insulin resistance; moreover, the risk of developing all the metabolic abnormalities is strongly associated with insulin resistance [9]. Dramatic increases in the prevalence of obesity during the second half of the last century have squarely placed adipose tissue at the center of scientific interest. This tissue now is not considered only as passive reservoir for storing excess energy substrates. Instead, adipose tissue is currently regarded as a highly metabolically active tissue that secretes many cytokines. Adipose tissue-derived cytokines or adipokines are involved in regulation of many vital processes such as energy metabolism, inflammation, and atherosclerosis. Thus, increased levels of adipokines and proinflammatory cytokines, such as TNF- $\alpha$, have prominent roles in the pathogenesis of the metabolic syndrome. Many studies confirm that the presence of the metabolic 
syndrome or any of its components correlates with the levels of adipokines [10]. Several studies have established an inverse relationship between the amount of physical activity and proinflammatory cytokines in obesity, diabetes, and the metabolic syndrome. Many believe that the beneficial effect of exercise is partly mediated through changes in the adipokines profile, that is, by increasing anti-inflammatory cytokines and decreasing proinflammatory ones [11-13]. This effect has been described at the levels of gene expression, protein ligands, and receptor bindings [14]. For instance, exercise increases insulin sensitivity through reduction of resting levels of TNF- $\alpha$ and CRP and augmentation of adiponectin levels [15]. This review summarizes some of the recent findings on the role of adipokines in obesity and the metabolic syndrome and how exercise may affect these changes. Unfortunately, there are not enough data available for most of the adipokines; thus, we selected adiponectin, leptin, TNF- $\alpha$, and IL- 6 as there is a reasonable amount of data on exercise induced changes on the profile of these adipokines.

\section{Physiologic Role of Adipokines}

2.1. Adiponectin. Human adiponectin consists of 244 amino acids and has a distinct domain structure with a collagen-like and a globular Clq-like domain (similar to the complement component C1q). This adipokine circulates in the blood in at least three homomeric complexes: trimer (low-molecular weight form, LMW), hexamer (medium molecular weight form, MMW), and higher order multimers (high molecular weight form, HMW) [16, 17]. Plasma concentrations reveal a sexual dimorphism, with females having higher levels than males [18]. The HMW form may be the most biologically active form regulating glucose homeostasis $[19,20]$. Although some studies show that the HMW form has a greater association with cardiovascular diseases [21], it has similar utility for the identification of insulin resistance and metabolic disturbances as does total adiponectin [22]. As opposed to other adipocytokines, plasma levels of adiponectin inversely correlates with body mass index (BMI), intra-abdominal fat, and indices of insulin resistance [23]. Plasma levels of adiponectin decrease with weight gain and are increased by weight loss [24, 25]. Many studies suggest that adiponectin is an important regulator of insulin sensitivity and glucose homeostasis, with several reports confirming an inverse relationship between insulin resistance and type II diabetes with plasma adiponectin levels [26-29]. It decreases hepatic glucose production and improves glucose uptake and fatty acid oxidation in skeletal muscles [30,31]. Adiponectin stimulates insulin secretion in vivo [32] while hypoadiponectinemia is associated with beta cell dysfunction $[33,34]$. Other studies show that adiponectin has anti-inflammatory effects, such as inhibition of endothelial nuclear factor kappa B (NF- $\kappa \mathrm{B})$, suppression of phagocytic activity, and TNF- $\alpha$ production in macrophages $[26,35,36]$. It also reduces the progression of atherosclerosis by decreasing the expression of adhesion molecules, reducing proliferation of vascular smooth muscle, and blocking transformation of macrophages to foam cells $[37,38]$. Crossing adiponectin transgenic mice with leptin deficient $o b / o b$ or apoE-deficient mice resulted in amelioration of insulin resistance, improved beta cell degranulation, increased expression of molecules involved in fatty acid oxidation, and attenuation of atherosclerosis [39]. Likewise, adiponectin null mice display severe hepatic insulin resistance [40]. On the other hand, adiponectin administration enhances insulin effects, improves glucose metabolism [30], and increases fatty acid oxidation and weight reduction [41].

Adiponectin exerts its function through activation of two kinds of receptors, adiponectin receptor 1 (AdipoR1) and adiponectin receptor 2 (AdipoR2). AdipoR1 receptors are found in different tissues and are connected to activation of $5^{\prime}$ AMP-activated protein kinase (AMPK) pathways while AdipoR2 receptors are mostly expressed in the liver and mainly linked to the activation of peroxisome proliferatoractivated receptor alpha (PPAR- $\alpha)$, reducing inflammation and oxidative stress [42]. Adenoviral selective expression of AdipoR1 receptors in $d b / d b$ mice leads to activation of AMPK and decreased expression of gluconeogenic enzymes such as glucose-6-phosphatase and phosphoenolpyruvate carboxykinase 1. Increased expression of enzymes regulating glucose uptake (such as glucokinase and PPAR- $\alpha$ ) results from enhanced hepatic expression of AdipoR2 receptors [42]. Expression of both receptors augments fatty acid oxidation and improves diabetes. Conversely, disruption of these receptors reduces the activity of related pathways and leads to significant glucose intolerance and aggravation of diabetes that is accompanied by increased hepatic triglyceride, inflammation, and oxidative stress [42].

The adiponectin gene is located on chromosome $3 \mathrm{q} 27$, which is related to type II diabetes and the metabolic syndrome $[43,44]$. Several common genetic variations of the human adiponectin gene have been identified. However, a limited number of single nucleotide polymorphisms (SNPs) have been associated with obesity, type II diabetes and coronary artery disease [43, 45-47]. The accumulated evidence thus supports the idea that obesity related diseases result from an interaction between genetic and environmental causes.

\subsection{Effect of Exercise on Adiponectin Levels. Since exercise} reduces insulin resistance and facilitates glucose metabolism, several studies have attempted to establish a relationship between exercise, adiponectin levels (or the expression of adiponectin receptors), and improvements in insulin function. However, in interpreting the findings of these experiments, it is necessary to consider the intensity and duration of the exercise protocols used and the diversity of human subjects. The form of measured adiponectin (total or multimers) is another variable. Overall, it would appear that acute episodes of mild or moderate exercise in healthy, lean subjects do not affect adiponectin levels [48-50]. A decrease in adiponectin levels occurs after acute strenuous rowing by young athletes; however, longer bouts of exercise are accompanied by increased expression of adiponectin mRNA levels in skeletal muscle [51]. In case of obese individuals, Jamurtas et al. evaluated the effects of a submaximal aerobic exercise bout on adiponectin, resistin, and insulin sensitivity in nine healthy overweight males. They 
found no significant correlation between assessed variables except among insulin level and insulin sensitivity (decreased postexercise insulin levels and increases in insulin sensitivity) [52]. Numao et al. investigated the influence of acute exercise of various intensities on changes in the concentrations of total adiponectin and adiponectin oligomers (HMW versus combination of LMW and MMW) in nine middle-aged abdominally obese men [53]. High intensity exercise decreased total adiponectin concentrations mainly by reducing LMW and MMW adiponectin levels without changing HMW adiponectin [53]. Conversely, a recent study of plasma adiponectin levels in inactive, abdominally obese men showed that both acute and short term (one week) aerobic exercise training significantly increased plasma values [54]. Chronic exercise protocols in both healthy and insulin resistant subjects also produced conflicting results in the literature, as shown in Table 1, which summarizes the results of some exercise protocols on adiponectin levels.

2.3. Leptin. The hormone leptin, whose nomenclature is derived from the Greek word "leptos" (means thin), is a $16 \mathrm{kDa}$ protein that has a primary role in suppressing appetite and increasing energy expenditure through metabolism. Leptin is primarily made in adipose tissue and its circulating levels correlate with body fat stores [55]. It is also expressed in the placenta, ovaries, mammary epithelium, bone marrow, and lymphoid tissues $[56,57]$. In humans, the leptin gene is located on chromosome 7 [58]. So far, six types of receptors have been recognized for leptin (Ob-Ra-Ob-Rf) that are all encoded by a single gene (LEPR). Ob-Re does not encode a transmembrane domain and is secreted and circulates in human plasma and represents the primary leptin-binding activity [59]. Ob-Ra and Ob-Rc have significant roles in transporting leptin across the blood brain barrier [60]. Ob$\mathrm{Rb}$ is the only receptor isoform that signals by intracellular mechanisms and this receptor is scattered throughout the central nervous system (CNS), particularly in hypothalamus, where it regulates energy homeostasis and neuroendocrine function $[61,62]$. Obesity and metabolic derangement in $d b / d b$ mice are the consequences of dysfunctional $\mathrm{Ob}-\mathrm{Rb}$ receptors. Janus-activated kinase (JAK), signal transducers and activators of transcription (STAT), insulin receptor substrate, and the mitogen-activated protein kinase (MAPK) pathways are important leptin intracellular signaling mechanisms [63]. The binding of leptin to its receptor leads to the formation of the Ob-R/JAK2 complex and activation of STAT3, which is phosphorylated and migrates to the nucleus presumably to affect changes in gene expression [64]. Binding of leptin receptors to JAK2 also results in JAK2 autophosphorylation [65], which in turn phosphorylates insulin receptor substrate proteins and involvement of phosphatidyl inositol 3-kinase to activate downstream signals [66].

Leptin is one of the best-known hormone markers for obesity and is very sensitive to levels of energy intake, particularly in energy deficient states. Two or three days of fasting lowers human plasma leptin levels even before any loss in body fat mass occurs $[67,68]$. Decreased leptin levels set off a series of biological reactions, including a reduction of sympathetic nervous system activity, thyroid hormones, hypothalamic gonadotropin-releasing hormones, insulin-like growth factor I (IGF-I), and augmentation of growth hormone (GH) and adrenocorticotropic hormone (ACTH), to reduce energy expenditure and prevent weight loss [69-73]. Conversely, adequate leptin levels promote energy expenditure through different effects on the endocrine (e.g., growth, reproduction, and immune system) and autonomic nervous system. Leptin deficiency in animals (ob/ob mice) and humans results in increased food intake, decreased energy expenditure, and infertility [74]. In spite of the appetite-lowering effects of leptin, the majority of obese individuals (except for rare cases of congenital leptin deficiency) show hyperleptinemia. These people are thought to be leptin resistant. The precise mechanisms of leptin unresponsiveness in obese individuals are yet to be determined; however, several mechanisms have been proposed to explain this phenomenon. Using an animal study, El-Haschimi et al. suggested that leptin may be unable to reach sites of action in the hypothalamus and/or that an intracellular reduction of leptin-mediated STAT signaling occurs [75]. Increased expression of suppressor of cytokine signaling-3 (SOCS-3), an inhibitor of postreceptor leptin signaling that lessens most of the ObRb signaling at chronically high levels of circulating leptin, is proposed as another mechanism [76]. Increased expression of SOCS-3 occurs in the vastus lateralis muscle of obese individuals [77] and diet-induced obese animals [78]. Similarly, SOCS3 deficient mice are protected against the development of hyperinsulinemia and insulin resistance during high fat diet induced obesity. These animals have increased expression of skeletal muscle insulin receptor substrate-1 (IRS-1) and Akt phosphorylation that results in increased skeletal muscle glucose uptake [79]. Persistent chronic inflammation and increased level of TNF- $\alpha$ may also play a role in hyperleptinemia of obese individuals as a positive correlation has been shown between TNF- $\alpha$ and leptin levels in both human and rodents $[80,81]$. The regulatory role of insulin and the effect of chronic hyperinsulinemia in increased leptin levels are another mechanism which remains to be clarified. In rodent, the stimulatory effect of insulin on leptin expression and secretion has been shown [82, 83]; however, such studies in human being were inconclusive [84].

2.4. Effect of Exercise on Leptin Levels. Because of the multifaceted role of leptin in human metabolism, many investigators evaluated the effect of different exercise protocols on leptin levels. Acute and short-term bouts of exercise do not affect leptin levels in healthy individuals [85]. However, longer durations of exercise $(\geq 60 \mathrm{~min})$ that are associated with increased energy expenditure $(\geq 800 \mathrm{kcal})$ can decrease leptin concentrations [86]. In an experiment with 45 men who participated in one of three competitive exercise protocols with approximately 1400, 5000, and 7000 Kcal energy expenditure, only the participants in the last two categories had reduced serum leptin levels; prompting the authors to conclude that only prolonged endurance exercise with large energy expenditure reduces circulating serum leptin 
TABLE 1: Summary of selected clinical trials in which adiponectin levels have been measured as a clinical outcome before and after exercise.

\begin{tabular}{|c|c|c|c|c|}
\hline Number & Subjects & Exercise intensity & Measured parameters & Results \\
\hline \multicolumn{5}{|c|}{ Measurement of adiponectin after exercise in healthy subjects } \\
\hline 48 & $\begin{array}{l}\text { Eight male and } 8 \\
\text { female healthy } \\
\text { subjects }\end{array}$ & $\begin{array}{l}60 \text { min stationary cycle } \\
\text { ergometry session at } 65 \% \\
\mathrm{VO}_{2} \max \end{array}$ & $\begin{array}{l}\text { Plasma adiponectin, TNF- } \alpha \text {, } \\
\text { insulin, glucose, and leptin }\end{array}$ & $\begin{array}{l}\text { Neither male nor female subjects } \\
\text { showed changes in adiponectin } \\
\text { and leptin concentrations }\end{array}$ \\
\hline 156 & Six healthy male & $\begin{array}{l}\text { (i) First experiment: } 30 \text { min of } \\
\text { heavy continuous running at } \\
79 \% \text { of } \mathrm{VO}_{2} \text { max } \\
\text { (ii) Second experiment: } \\
\text { strenuous intermittent exercise } \\
\text { consisting of treadmill running at } \\
60,75,90 \text {, and } 100 \% \text { of } \mathrm{VO}_{2} \max \end{array}$ & $\begin{array}{l}\text { Serum concentration of } \\
\text { adiponectin, insulin, and plasma } \\
\text { concentrations of glucose and } \\
\text { lactate }\end{array}$ & $\begin{array}{l}\text { No significant change in } \\
\text { adiponectin concentrations in } \\
\text { either of these protocols }\end{array}$ \\
\hline 49 & $\begin{array}{l}\text { Ten active male } \\
\text { subjects }\end{array}$ & $\begin{array}{l}\text { Two similar trials, each trial } \\
\text { consisted of } 120 \text { min cycling } \\
\text { exercise at } 50 \% \mathrm{VO}_{2} \max \end{array}$ & $\begin{array}{l}\text { (i) Plasma adiponectin, FFA, and } \\
\text { glycerol concentrations } \\
\text { (ii) Determining adiponectin } \\
\text { protein and adiponectin receptor } \\
\text { mRNA expression in skeletal } \\
\text { muscle }\end{array}$ & $\begin{array}{l}\text { No change in plasma adiponectin } \\
\text { concentration and tissue mRNA } \\
\text { expression of adiponectin } \\
\text { receptors }\end{array}$ \\
\hline 157 & 24 healthy male & $\begin{array}{l}\text { Endurance or resistance training } \\
3 \text { days/week for } 12 \text { weeks } \\
\text { (i) Endurance training } \\
\text { (continuous running at } 75-85 \% \\
\text { of MHR) } \\
\text { (ii) Resistance training } \\
\text { ( } 4 \text { sets of circuit weight training } \\
\text { for } 11 \text { stations at } 50-60 \% \text { of } \\
\text { one-repetition maximum) }\end{array}$ & $\begin{array}{l}\text { Serum glucose, insulin, and } \\
\text { adiponectin }\end{array}$ & $\begin{array}{l}\text { Endurance and resistance } \\
\text { training were not accompanied } \\
\text { by increased adiponectin levels }\end{array}$ \\
\hline \multicolumn{5}{|c|}{ Measurement of adiponectin after exercise in obese subjects } \\
\hline 158 & $\begin{array}{l}16 \text { obese men and } \\
\text { women (age, 63) }\end{array}$ & $\begin{array}{l}\text { 12-week supervised exercise ( } 5 \\
\text { days/wk, } 60 \mathrm{~min} / \text { day, } \\
\text { treadmill/cycle ergometry at } 85 \% \\
\text { of max HR) }\end{array}$ & $\begin{array}{l}\text { Insulin resistance, fat mass, } \\
\text { adiponectin, TNF- } \alpha \text {, and leptin } \\
\text { levels }\end{array}$ & $\begin{array}{l}\text { Exercise reversed insulin } \\
\text { resistance but there was no } \\
\text { change in leptin and adiponectin } \\
\text { levels }\end{array}$ \\
\hline 159 & $\begin{array}{l}19 \text { overweight and } \\
\text { obese girls }\end{array}$ & $\begin{array}{l}12 \text { weeks of supervised training } \\
(3 \mathrm{~d} / \mathrm{wk}, 40 \text { min each session })\end{array}$ & $\begin{array}{l}\text { Insulin sensitivity, adiponectin, } \\
\text { CRP, IL-6, IGF-1, blood lipids, } \\
\text { and so forth }\end{array}$ & $\begin{array}{l}\text { Insulin sensitivity improved } \\
\text { without change in adiponectin } \\
\text { and leptin }\end{array}$ \\
\hline 160 & $\begin{array}{l}25 \text { obese sedentary } \\
\text { premenopausal } \\
\text { women }\end{array}$ & $\begin{array}{l}12 \text { weeks of aerobic exercise } \\
\text { program }\left(5 \mathrm{~d} / \mathrm{wk}, 50 \% \text { of } \mathrm{VO}_{2}\right. \\
\max )\end{array}$ & $\begin{array}{l}\text { Plasma and mRNA levels of } \\
\text { leptin, adiponectin, IL- } 6 \text {, and } \\
\text { TNF- } \alpha\end{array}$ & $\begin{array}{l}\text { Plasma leptin level decreased } \\
\text { while plasma levels of other } \\
\text { cytokines remained unchanged }\end{array}$ \\
\hline 161 & 26 overweight males & $\begin{array}{l}10 \text { weeks of aerobic exercise } \\
(4-5 \mathrm{~d} / \text { wk, } 40 \text { min each session, } \\
\text { brisk walking mixed with light } \\
\left.\text { jogging, } 55-70 \% \mathrm{VO}_{2} \max \right)\end{array}$ & $\begin{array}{l}\text { Insulin sensitivity, indirect } \\
\text { calorimetry, and plasma } \\
\text { adiponectin level }\end{array}$ & $\begin{array}{l}\text { Adiponectin levels rose by } 260 \% \\
\text { after 2-3 bouts of exercise (1 } \\
\text { week) without any change in BW }\end{array}$ \\
\hline 162 & $\begin{array}{l}\text { Eight obese female } \\
\text { students and } 8 \text { obese } \\
\text { controls }\end{array}$ & $\begin{array}{l}7 \text { mo exercise training } \\
(30-60 \mathrm{~min} / \mathrm{d}, 4-5 \mathrm{~d} / \mathrm{wk} 60-70 \% \\
\text { of HR-reserve) }\end{array}$ & $\begin{array}{l}\text { Adiponectin, leptin, hs-CRP, } \\
\text { TNF- } \alpha \text {, and lipid profile }\end{array}$ & $\begin{array}{l}\text { Exercise decreased BW, body fat } \\
\text { mass, hs-CRP, leptin, and TNF- } \alpha \\
\text { and increased HDL, } \mathrm{VO}_{2} \max , \\
\text { and adiponectin }\end{array}$ \\
\hline
\end{tabular}

BW: body weight; FFA: free fatty acids; HR: heart rate; hs-CRP: high sensitivity $\mathrm{C}$ reactive protein; MHR: maximal heart rate; $\mathrm{VO}_{2}$ max: maximal oxygen consumption; wk: week.

levels [87]. Short-term exercise training ( $\leq 12$ weeks) is not associated with significant changes in leptin levels, yet there are variable reports when training courses last more than 3 months. Generally speaking, those training protocols which lower adiposity will result in diminished leptin levels.

An important point of interest in measuring leptin levels is paying attention to diurnal variations in its blood levels. Kraemer et al. determined leptin levels in 15 healthy postmenopausal women at baseline, exercise, and recovery point intervals. Blood sampling with the same time intervals but without exercise was performed one month later as a control group. Even though no difference was detected between two groups, there was a gradual decrease from baseline levels to postexercise and recovery period. They emphasized the need to account for diurnal variations in measuring leptin levels over the course of exercise trials [88].

Diabetic patients seem to be more responsive to the leptin lowering effects of exercise, as acute and short bouts of 
exercise can reduce leptin levels in such patients. Kanaley et al. reported a decrease in leptin levels after an acute episode of exercise in diabetic (not healthy) subjects, as measured after 6 weeks of training [89]. This increased sensitivity to exerciseinduced lowering effect of plasma leptin levels remains in the offspring of diabetic patients [90]. Table 2 summarizes some of the clinical trials which have studied the effects of exercise on leptin levels in different groups of people.

2.5. Tumor Necrosis Factor-Alpha (TNF- $\alpha)$. TNF- $\alpha$ is a cytokine that is mainly produced by monocytes and macrophages. It is also secreted by other immunogenic cells such as CD4 lymphocytes and natural killer cells and plays major roles in cell death (apoptosis), inflammation, and induction of acute phase reactants. In obese individuals, macrophage-infiltrated visceral fat is the main site of TNF- $\alpha$ production [91]. Expression levels of the TNF gene are higher in abdominal adipose tissue compared to subcutaneous fat, and, importantly, greater TNF gene expression occurs in the adipose tissues of obese animals [92] and humans [93]. Accumulating data suggests a direct relationship between TNF- $\alpha$ plasma levels and insulin resistance. For instance, in both $o b / o b$ and diet-induced obese mice, genetic deletion of TNF- $\alpha$ or its receptors significantly reduced insulin resistance and improved insulin signaling in muscle and adipose tissue [94]. Also, based on a community-based cohort study, it is proposed that the prevalence of insulin resistance increases with greater levels of resistin and TNF- $\alpha$ and is inversely related to adiponectin levels [95]. Diabetic patients have high activity of TNF- $\alpha$ in the plasma and skeletal muscles [96-98].

At a cellular level, TNF-dependent activation of stressrelated kinases inhibits insulin signaling, causing cellular insulin resistance. Some of these stress-related kinases also promote further production of TNF, perpetuating a positive feedback mechanism for sustained TNF activity and chronic insulin resistance [99]. Targeted disruptions of genes encoding TNF [94] or TNF receptors [100] markedly improve insulin sensitivity in obese mice. On the other hand, visceral fat obesity is associated with decreased concentrations of insulin-sensitizing and anti-inflammatory adipokines [101]. During lipolytic activity, more fatty acids are released from visceral adipose tissue compared to subcutaneous adipose tissue $[102,103]$, as visceral fat has a higher metabolic rate and has increased susceptibility to lipolytic enzymes [104]. Antilipolytic activity of insulin also has a lesser influence on visceral fat [105] (Table 3). Increased TNF level induces hepatic uptake of these fatty acids in a process that is accompanied by reduced fatty acid oxidation and triglyceride export. These events cause accumulation of fat within hepatocytes (hepatic steatosis). Direct drainage of visceral fatinduced FFAs through porta vein is another factor in the pathogenesis of fatty liver. Indeed, nonalcoholic fatty liver disease commonly accompanies the metabolic syndrome. It is generally believed that the chain of reactions leading to hepatocyte fatty degeneration begins with increased levels of TNF and insulin resistance, which precede fat accumulation [106]. During hepatic insulin resistance, hepatic glucose production is no longer downregulated by insulin, resulting in increased hepatic glucose production and stimulation of increased insulin secretion. Chronic hyperinsulinemia desensitizes peripheral tissues to insulin and causes systemic insulin resistance. Insulin resistance increases adipocyte lipolysis, resulting in the release of large amounts of fatty acids into the blood and exacerbation of hepatic steatosis and insulin resistance [107] (Figure 1). TNF- $\alpha$ also promotes the incorporation of fatty acids into diacylglycerol, which may contribute to the development of TNF- $\alpha$ induced insulin resistance in skeletal muscle [108].

TNF is also a potent inducer of mitochondrial ROS and increases ROS production in fatty hepatocytes [109]. In order to mitigate or reverse this chronic oxidative stress, adaptive mechanisms such as uncoupling proteins are activated or upregulated. The controlled transfer of protons can uncouple mitochondrial respiration across the inner mitochondrial membrane, thereby dissipating the proton gradient and reducing the harmful effects of ROS. The inner mitochondrial membrane uncoupling proteins play important roles in thermogenesis of brown adipose tissue and in regulating the disposal of mitochondrial ROS in other tissues [110]. Decreases in the mitochondrial membrane potential reduce ATP synthesis and make cells susceptible to necrotic cell death [111]. These events lead to local inflammatory reactions by attracting inflammatory cells, leading to the histopathology of nonalcoholic steatohepatitis [112].

2.6. Effect of Exercise on TNF- $\alpha$ Level. A large body of evidence shows an inverse relationship between plasma levels of inflammatory adipokines and the amount of physical activity. Even though acute episodes of exercise might be associated with increased levels of inflammatory cytokines, exercise training reduces circulating levels of inflammatory markers, even in lean individuals [113]. Controlling the release and activity of at least two cytokines, namely, TNF- $\alpha$ and IL-6, could contribute to the natural protective effects of physical activity in the metabolic syndrome. Exercise confers protection against TNF- $\alpha$ induced insulin resistance [114] while it reduces CRP, IL-6, and TNF- $\alpha$ levels and increases anti-inflammatory substances such as IL-4 and IL-10 [115, 116]. The association between the metabolic syndrome and inflammation is well documented $[117,118]$. The reduction in TNF- $\alpha$ by exercise may be exerted through both IL- 6 (muscle-derived) dependent and independent pathways [119, 120]. Furthermore, exercise induced increases in epinephrine levels can also blunt the TNF- $\alpha$ response by a poorly defined mechanism [121]. Weight reduction through exercise (and diet) decreases the volume and number of adipocytes and also reduces the number of endothelial and macrophage cells that are lodged inside adipose tissue that produce proinflammatory mediators. Increased production of anti-inflammatory mediators by adipocytes and decreased hepatic production of fibrinogen and other proinflammatory mediators are other consequences of exercise-induced weight reduction. Weight loss also influences the immune system by reducing the number of mononuclear cells in the circulation; these are important sources of proinflammatory cytokines [122]. The effect 
TABLE 2: Summary of selected clinical trials in which leptin levels were measured as a clinical outcome before and after exercise.

\begin{tabular}{|c|c|c|c|c|}
\hline Number & Subjects & Exercise intensity & Measured parameters & Results \\
\hline \multicolumn{5}{|c|}{ Acute and short ( $\leq 60 \mathrm{~min}$ ) exercise protocols without significant effect on leptin levels } \\
\hline 163 & $\begin{array}{l}\text { Seven young men } \\
\text { (age, 27) }\end{array}$ & $\begin{array}{l}30 \text { min Ex at } 25 \% \text { and } 75 \% \text { of the } \\
\text { difference between the lactate } \\
\text { threshold (LT) and rest ( } 0.25 \mathrm{LT} \text {, } \\
0.75 \mathrm{LT} \text { ), at LT, and at } 25 \% \text { and } \\
75 \% \text { of the difference between LT } \\
\left.\text { and } \mathrm{VO}_{2} \text { peak ( } 1.25 \mathrm{LT}, 1.75 \mathrm{LT}\right)\end{array}$ & $\begin{array}{l}\text { Leptin AUC for all six } \\
\text { conditions }\end{array}$ & $\begin{array}{l}30 \text { min Ex at different intensities } \\
\text { does not affect leptin levels } \\
\text { during or up to } 3.5 \text { hours after } \\
\text { exercise }\end{array}$ \\
\hline 164 & $\begin{array}{l}\text { Six healthy untrained } \\
\text { men }\end{array}$ & $\begin{array}{l}\text { Three sessions of control, Max } \\
\text { Ex, and prolonged Ex at } 50 \% \text { of } \\
\mathrm{VO}_{2} \max \end{array}$ & $\begin{array}{l}\text { Serum leptin, insulin, } \\
\text { glucose, FFA, and glycerol } \\
\text { REE and BF were also } \\
\text { assessed }\end{array}$ & $\begin{array}{l}\text { (i) No significant differences } \\
\text { were observed in leptin } \\
\text { concentrations between the } \\
\text { control and exercise session } \\
\text { (ii) Control serum leptin was } \\
\text { positively correlated to BF and } \\
\text { glucose and negatively correlated } \\
\text { to REE }\end{array}$ \\
\hline 83 & $\begin{array}{l}15 \text { healthy } \\
\text { postmenopausal } \\
\text { women ( } 8 \text { on HRT } \\
\text { and } 7 \text { on NHRT) }\end{array}$ & $\begin{array}{l}30 \text { min treadmill at } 80 \% \mathrm{VO}_{2} \\
\max \end{array}$ & $\begin{array}{l}\text { Leptin level before and after } \\
\text { exercise session and one } \\
\text { month later as (without } \\
\text { exercise) control values }\end{array}$ & $\begin{array}{l}\text { No significant differences were } \\
\text { observed between groups }\end{array}$ \\
\hline 165 & $\begin{array}{l}\text { Eight young, lean, } \\
\text { sedentary men }\end{array}$ & $\begin{array}{l}41 \text { min of cycle ergometry at } 85 \% \\
\text { of } \mathrm{VO}_{2} \text { max and } 1-2 \text { weeks later } \\
\text { the same protocol but without } \\
\text { exercise to be considered as } \\
\text { control }\end{array}$ & $\begin{array}{l}\text { Serum leptin, insulin, } \\
\text { protein, and cortisol levels } \\
\text { plus plasma glucose, EP, } \\
\text { and NE concentrations }\end{array}$ & $\begin{array}{l}\text { No significant changes in leptin } \\
\text { levels }\end{array}$ \\
\hline 166 & $\begin{array}{l}\text { Ten young lean men } \\
(\text { age, 23) }\end{array}$ & $\begin{array}{l}\text { Acute effects of } 3 \text { resistance } \\
\text { exercise protocols including MS, } \\
\mathrm{MH} \text {, and SE on serum leptin }\end{array}$ & $\begin{array}{l}\text { Serum leptin, cortisol, } \\
\text { glucose, and GH }\end{array}$ & $\begin{array}{l}\text { Typical resistance exercise } \\
\text { protocols did not result in serum } \\
\text { leptin changes }\end{array}$ \\
\hline
\end{tabular}

Longer duration ( $\geq 60 \mathrm{~min}$ ) exercise protocols which resulted in decreased leptin levels

12 fasted men (age,

30) to work on

167 stationary cycle ergometer and 14 nonfasted marathon runner (age, 41)

29 male marathon runner compared with 22 age-, sex-, and BMI-matched sedentary controls 9 trained men (age, 22-33) Ten young men (age, 21)

Intense exercise in both groups (four half-hour period at 75\% $\mathrm{VO}_{2}$ max for cyclists and 101 mile running for runners)

Marathon run $(42.195 \mathrm{~km})$ with a calculated energy expenditure of over $2800 \mathrm{Cal}$

(i) A MAX short duration run (ii) 60 min endurance ran at $70 \%$ of $\mathrm{VO}_{2}$ max consumption (END)

Acute heavy resistance protocol (50 total set comprised of the squat, bench press, and lat pull-down)

(i) A half marathon run

45 males participated 82
(21.097 Km, $1400 \mathrm{Kcal})$

(ii) A ski-alpinism $(45 \mathrm{Km}$, $5000 \mathrm{Kcal})$

(iii) An ultramarathon race $(100 \mathrm{Km}, 7000 \mathrm{Kcal})$
Blood leptin levels before, at the end, 6,18 , and 24 hours after exercise

Leptin levels one day before and after run

Plasma leptin, insulin, and glucose levels before, immediately after, 24 , and 48 hours after exercise

Plasma leptin levels

(i) Serum leptin

(ii) Plasma free fatty acids
Negative energy balance of exercise can reduce serum leptin concentrations

There was a significant reduction in blood leptin levels in runners

(i) Plasma leptin levels did not differ between time points for the MAX run

(ii) Leptin was significantly lower $48 \mathrm{~h}$ after exercise in END group Leptin concentration showed a delayed (approximately $9 \mathrm{~h}$ ) reduction after acute resistance exercise

Serum leptin levels decreased significantly in ultramarathon and ski-alpinism but not in half marathon run 
TABLE 2: Continued.

\begin{tabular}{|c|c|c|c|c|}
\hline Number & Subjects & Exercise intensity & Measured parameters & Results \\
\hline \multicolumn{5}{|c|}{ Exercise protocols in obese, prediabetic, and/or metabolic syndrome patients } \\
\hline 171 & $\begin{array}{l}\text { Fifty inactive men } \\
\text { (age, 65-78, BMI, } \\
28.7-30)\end{array}$ & $\begin{array}{l}\text { Low intensity }(n=14) \\
\text { Moderate intensity }(n=12) \\
\text { High intensity }(n=14) \\
\text { Control }(n=10) \\
\text { For } 24 \text { weeks }\end{array}$ & $\begin{array}{l}\text { Exercise energy cost } \\
\text { Skinfold sum } \\
\text { Body weight } \\
\mathrm{VO}_{2} \text { max } \\
\text { Resting metabolic rate } \\
\text { Plasma leptin and } \\
\text { adiponectin }\end{array}$ & $\begin{array}{l}\text { Leptin was diminished by all } \\
\text { treatments }\end{array}$ \\
\hline 172 & $\begin{array}{l}50 \text { sedentary type II } \\
\text { diabetic subjects } \\
\text { divided to a diet } \\
\text { therapy }(n=23) \\
\text { group or an exercise } \\
\text { plus diet therapy } \\
\text { group }\end{array}$ & $\begin{array}{l}\text { Exercise protocol consisted of } \\
\text { walking and cycle ergometer } \\
\text { exercise for } 1 \mathrm{~h} \times 5 / \text { week with the } \\
\text { intensity of } 50 \% \text { of } \mathrm{VO}_{2} \max \end{array}$ & $\begin{array}{l}\text { Plasma leptin levels } \\
\text { Fasting plasma insulin, } \\
\text { glucose, cortisol, and } \\
\text { HbAlc } \\
\text { Urinary 17-OHCS }\end{array}$ & $\begin{array}{l}\text { Leptin significantly decreased in } \\
\text { exercise group }\end{array}$ \\
\hline 84 & $\begin{array}{l}30 \text { men and women } \\
\text { (17 controls and } 13 \\
\text { type II obese } \\
\text { diabetics, age } 40-55)\end{array}$ & $\begin{array}{l}\text { Three repetition of maximal } \\
\text { weight lifting bout } 72 \mathrm{~h} \text { after their } \\
\text { last training bout of } 6 \text { weeks of } \\
\text { resistance training }\end{array}$ & $\begin{array}{l}\text { Serum leptin levels plus } \\
\text { glucose and insulin }\end{array}$ & $\begin{array}{l}\text { Acute exercise decreased leptin } \\
\text { level in diabetic group }\end{array}$ \\
\hline 85 & $\begin{array}{l}34 \text { women offspring } \\
\text { of type II diabetic } \\
\text { patients and } 36 \\
\text { matched female } \\
\text { controls }\end{array}$ & $\begin{array}{l}\text { Seven weeks of exercise } \\
\text { intervention }\end{array}$ & $\begin{array}{l}\text { Insulin sensitivity index, } \\
\mathrm{VO}_{2} \text { max, and plasma } \\
\text { leptin level }\end{array}$ & $\begin{array}{l}\text { Plasma leptin levels decreased } \\
\text { only in the offspring of diabetic } \\
\text { patients }\end{array}$ \\
\hline 173 & $\begin{array}{l}50 \text { diabetic men } \\
\text { divided to exercise } \\
\text { training or standard } \\
\text { therapy for } 2 \text { years }\end{array}$ & $\begin{array}{l}\text { Endurance and muscle strength } \\
\text { training } 4 \text { times/week. }\end{array}$ & $\begin{array}{l}\text { HbAlc, insulin, leptin, } \\
\text { blood lipids, blood } \\
\text { pressure, } \mathrm{VO}_{2} \text { max, and } \\
\text { muscle strength }\end{array}$ & $\begin{array}{l}\mathrm{VO}_{2} \text { max, muscle strength, } \\
\mathrm{HbAlc} \text {, and leptin improved in } \\
\text { exercise group }\end{array}$ \\
\hline
\end{tabular}

AUC: area under curve; BF: body fat; EP: epinephrine; Ex: exercise; FFA: free fatty acids; GH: growth hormone; HRT: hormone replacement therapy; MAX: maximum intensity; MH: muscular hypertrophy; MS: maximum strength; NE: norepinephrine; NHRT: nonhormone replacement therapy; 17-OHCS: 17hydroxycorticosteroid; REE: resting energy expenditure; SE: strength endurance; $\mathrm{VO}_{2}$ max: maximal oxygen consumption.

TABLE 3: Some differences between visceral and subcutaneous adipose tissue [105].

\begin{tabular}{lcc}
\hline & $\begin{array}{c}\text { Visceral } \\
\text { fat }\end{array}$ & $\begin{array}{c}\text { Subcutaneous } \\
\text { fat }\end{array}$ \\
\hline $\begin{array}{l}\text { Sensitivity to catecholamine induced } \\
\text { lipolysis }\end{array}$ & Higher & Lower \\
$\begin{array}{l}\text { Sensitivity to insulin's antilipolytic } \\
\text { effects }\end{array}$ & Lower & Higher \\
$\begin{array}{l}\text { Density of glucocorticoid receptors } \\
\text { Androgen receptors }\end{array}$ & Higher & Lower \\
$\begin{array}{l}\text { Leptin secretion and leptin mRNA } \\
\text { expression }\end{array}$ & Higher & Lower \\
Secretion of IL-6 (as an adipokine) & Higher & Lower \\
\hline
\end{tabular}

of exercise training on reducing the expression of TNF- $\alpha$ in white adipose tissue has been shown in several animal studies, as well [123-125]. Table 4 summarizes the results of some clinical trials that measured TNF- $\alpha$ after exercise training in humans.

2.7. Interleukin-6 (IL-6). IL-6 belongs to a family of cytokines that collectively have an important role in immune reactions, hematopoiesis, and metabolism. IL-6 has both pro- and antiinflammatory effects and is classified as an adipokine as well as a myokine and causes a wide range of sometimes contradictory effects. The physiologic nature of target cells and specific in vivo conditions are confounding factors in determining its final biological effect [126]. Indeed, IL-6 is a good example of a chemical that is able to cause cross talk amongst different tissues.

There are conflicting reports about the effect(s) of IL-6 on lipid and glucose metabolism and insulin sensitivity. The release of the adipokine IL- 6 is related to BMI [127129]. Fernandez-Real et al. demonstrated a positive association between IL- 6 concentrations and the fasting insulin resistance index in 228 healthy volunteers [130]. Subcutaneous injections of recombinant human IL-6 also increase blood glucose and glucagon levels without changes in C-peptide levels, supporting the idea that IL-6 alters insulin sensitivity [131]. Moreover, IL-6 impairs insulin signaling in adipocytes and reduces insulin-dependent glucose uptake by reducing GLUT4 expression and IRS-1 [132]. The disturbing effect of IL-6 on insulin signaling also occurs in mouse hepatocytes and human hepatocarcinoma cells [133]. These data collectively suggest that IL-6 impairs insulin sensitivity. On the other hand, Carey et al. reported that infusion of IL-6 to seven healthy males accelerated glucose 


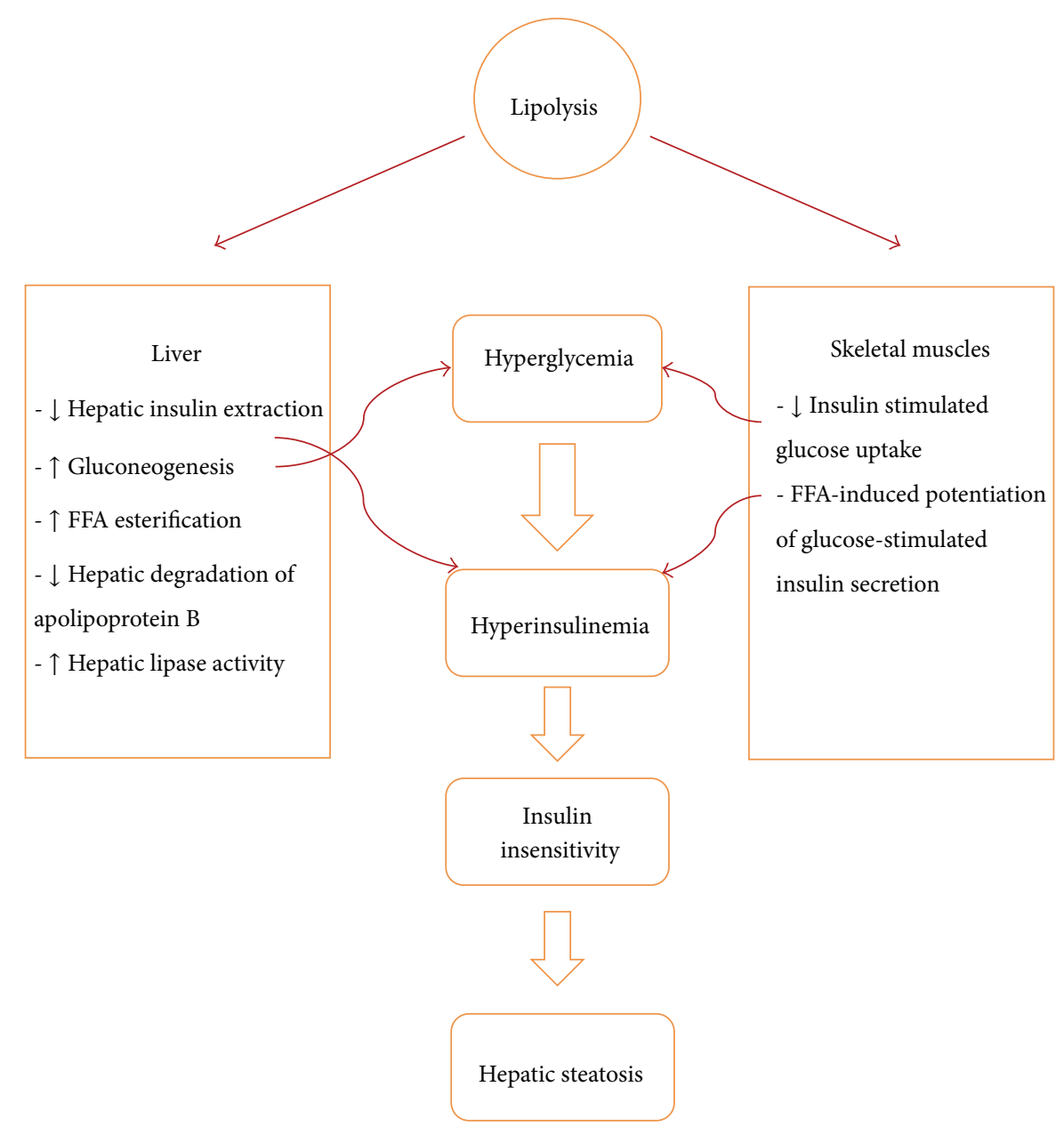

FIGURE 1: Some of the pathophysiologic mechanisms involved in the pathogenesis of fatty liver.

removal with no effects on endogenous glucose production during a hyperinsulinemic-euglycemic clamp study. They also reported that IL-6 improved basal and insulin-stimulated glucose uptake by myocytes, an effect that was mediated by translocation of GLUT4 transporters to the plasma membrane [134]. Similarly, an acute infusion of IL-6 improved insulin sensitivity and glucose removal in animal studies [135]. One explanation for this discrepancy in the effects of IL- 6 effect on glucose metabolism could be the time course of IL-6 elevation. Chronic elevation of IL-6 levels in obese and type II diabetics may be associated with insulin resistance, while acute transient increase can enhance insulin sensitivity. However, this speculation is not supported in an animal study in which chronic infusion (14 days) of IL-6 increased insulin sensitivity [135].

IL-6 mRNA is upregulated in contracting skeletal muscle [136], and the transcriptional rate of the IL- 6 gene is also markedly enhanced by exercise [137]. Physical training augments the expression of IL-6 receptors in human skeletal muscle and sensitizes them to IL- 6 at rest [138]. Of interest is that connective tissue located in and around working muscles may have an additional role in the production and secretion of IL-6 to the plasma [139]. Availability of energy resources can also affect intramuscular IL-6 mRNA levels in response to exercise as this response is higher under glycogen depleted conditions [140] and following prolonged and strenuous activities [141]. Lipid turnover, lipolysis, and fat oxidation, via activation of AMP-activated protein kinase are enhanced by IL-6 [142]. This is supported by studies showing that IL-6 deficient mice (IL- $6^{-} /^{-}$) develop mature onset obesity and have disturbed carbohydrate and lipid metabolism that is partly reversed by IL- 6 replacement [143]. Infusion of IL-6 to human subjects increases systemic fatty acid oxidation [144]. The lipolytic effect of IL-6 on fat metabolism was confirmed in two clinical studies of healthy and diabetic subjects $[142,145]$. A recent study reported that exerciseinduced increases in IL-6 production could improve insulin secretion through stimulating glucagon-like peptide-1 (GLP1) secretion, a hormone that induces insulin secretion. This newly explained mechanism adds to the importance of IL-6 as a mediator of cross talk between different tissues [146].

Collectively, it can be inferred that IL- 6 has regulatory effects on metabolism of both adipose and muscular tissue and is a mediator of cross talk between these two compartments. Excessive production of IL-6, as an adipokine, in obesity and diabetes, has an adverse effect on glucose 
TABLE 4: Summary of selected clinical trials in which TNF- $\alpha$ level has been measured as a clinical outcome before and after exercise.

\begin{tabular}{|c|c|c|c|c|}
\hline Number & Subjects & Exercise intensity & Measured parameters & Results \\
\hline 174 & $\begin{array}{l}67 \text { healthy, premenopausal } \\
\text { women and } 40 \text { age matched } \\
\text { normal weight women }\end{array}$ & $\begin{array}{l}\text { Walk for at least } 1 \mathrm{~h} \text { three } \\
\text { times a week plus a diet } \\
\text { contained } 1300 \mathrm{Kcal} / \mathrm{d} \text { and } \\
\text { behavioral counseling }\end{array}$ & $\begin{array}{l}\text { Echocardiography plus } \\
\text { circulating levels of TNF- } \alpha \text {, } \\
\text { IL-6, IL-8, and CRP }\end{array}$ & $\begin{array}{l}\text { After one year, there was a } \\
\text { significant reduction in } \\
\text { inflammatory markers and } \\
\text { improvement in cardiac } \\
\text { function }\end{array}$ \\
\hline 175 & $\begin{array}{l}23 \text { overweight and obese } \\
\text { adults are randomized into vit } \\
\mathrm{D}+\text { exercise and exercise } \\
\text { group }\end{array}$ & $\begin{array}{l}\text { All participants did } \\
12 \text {-week }(3 \mathrm{~d} / \mathrm{wk}) \\
\text { progressive resistance } \\
\text { exercise at } 70-80 \% \text { of one } \\
\text { repetition maximum }\end{array}$ & $\begin{array}{l}\text { Stimulated TNF- } \alpha \text {, } \\
\text { circulating CRP, TNF- } \alpha \text {, } \\
\text { IL-6, and ALT }\end{array}$ & $\begin{array}{l}\text { Both groups had a } \\
\text { significant reduction in } \\
\text { nonstimulated TNF- } \alpha \\
\text { production after } 12 \text { weeks }\end{array}$ \\
\hline 176 & $\begin{array}{l}82 \text { subjects with type II } \\
\text { diabetes and metabolic } \\
\text { syndrome are randomized to } \\
\text { following groups: } \\
20 \text { T2D (sedentary control, A) } \\
20 \text { T2D (low intensity aerobic } \\
\text { exercise, B) } \\
20 \text { T2D (high intensity aerobic } \\
\text { exercise, C) } \\
22 \text { T2D (aerobic and } \\
\text { resistance exercise, D) }\end{array}$ & $\begin{array}{l}\text { Twice a week supervised } \\
\text { sessions of } 60 \text { min of } \\
\text { aerobic exercise at } 70-80 \% \\
\mathrm{VO}_{2} \text { max for group C } \\
\text { patients and } 40 \text { min aerobic } \\
\text { exercise at } 70-80 \% \mathrm{VO}_{2} \\
\text { max }+20 \text { min resistance } \\
\text { exercise at } 80 \% \text { of } 1 \\
\text { repetition maximum for } \\
\text { Group D subjects. group B } \\
\text { received counseling to } \\
\text { perform low intensity } \\
\text { physical activities. These } \\
\text { protocols continued for } 12 \\
\text { months }\end{array}$ & $\begin{array}{l}\text { HbAlc, FBS, TG, TC, HDL, } \\
\text { hs-CRP, IL- } 1 \beta \text {, IL- } 4 \text {, IL- } 6 \text {, } \\
\text { IL-10, TNF- } \alpha \text {, IFN- } \gamma \text {, } \\
\text { leptin, resistin, and } \\
\text { adiponectin } \mathrm{VO}_{2} \text { max }\end{array}$ & $\begin{array}{l}\text { (i) Significant decrease of } \\
\text { hs-CRP in groups C and D } \\
\text { (ii) Leptin, resistin, and } \\
\text { IL- } 6 \text { decreased in groups C } \\
\& \text { D, while adiponectin } \\
\text { increased } \\
\text { (iii) IL-1 } \beta \text {, TNF- } \alpha \text {, and } \\
\text { IFN- } \gamma \text { decreased in group } \\
\text { D, whereas } \\
\text { anti-inflammatory IL- } 4 \& \\
10 \text { levels declined }\end{array}$ \\
\hline 177 & $\begin{array}{l}31 \text { inactive subjects with } \\
\text { metabolic syndrome are } \\
\text { divided to } \\
\text { (i) High-intensity aerobic } \\
\text { interval training (AIT), } \\
\text { (ii) strength training (ST), } \\
\text { (iii) control group }\end{array}$ & $\begin{array}{l}\text { Exercise training was } \\
\text { carried out three times per } \\
\text { week for } 12 \text { weeks }\end{array}$ & $\begin{array}{l}\text { Serum insulin, hs-CRP, } \\
\text { IL-18, IL-6, and TNF- } \alpha\end{array}$ & $\begin{array}{l}\text { Serum IL-18 was reduced } \\
\text { after AIT } \\
\text { TNF- } \alpha \text { level was lower in } \\
\text { AIT group compared to ST } \\
\text { and controls } \\
\text { No changes in serum IL-6, } \\
\text { insulin, or hs-CRP within } \\
\text { or between the groups }\end{array}$ \\
\hline 178 & $\begin{array}{l}20 \text { obese individuals (BMI, 32) } \\
\text { with at least one other } \\
\text { component of the metabolic } \\
\text { syndrome are randomized to } \\
\text { exercise group and diet group } \\
\text { after } 8 \text { weeks of control period }\end{array}$ & $\begin{array}{l}\text { Exercise consisted of } 8 \\
\text { weeks of moderate cycling } \\
\text { exercise ( } 30 \mathrm{~min}, 3 \\
\text { times/wk) }\end{array}$ & $\begin{array}{l}\text { Fasting glucose and insulin } \\
\text { levels } \\
\text { Muscle biopsy for analysis } \\
\text { of skeletal muscle TNF- } \alpha \\
\text { and GLUT4 }\end{array}$ & $\begin{array}{l}\text { Both interventions reduced } \\
\text { plasma insulin levels } \\
\text { Only diet reduced muscle } \\
\text { TNF- } \alpha \text { but exercise did not } \\
\text { change TNF- } \alpha \text { protein } \\
\text { expression }\end{array}$ \\
\hline 179 & $\begin{array}{l}47 \text { obese diabetic patients } \\
\text { randomly assigned to aerobic } \\
(\mathrm{AT}, n=27) \text { or aerobic plus } \\
\text { resistance (ART, } n=20) \\
\text { exercise protocols }\end{array}$ & $\begin{array}{l}\text { AT program was } 15 \mathrm{~min} \\
\text { row ergometer plus } 15 \mathrm{~min} \\
\text { bicycle ergometer at } 70 \% \text { of } \\
\text { HR max for } 5 \mathrm{~d} / \mathrm{wk} \\
\text { ART program was AT } \\
\text { program plus } 15 \mathrm{~min} \\
\text { resistance training at } \\
40-50 \% \text { of HR max }\end{array}$ & $\begin{array}{l}\text { Blood glucose, insulin, and } \\
\text { lipid profile } \\
\text { Leptin, adiponectin, } \\
\text { resistin, TNF- } \alpha \text {, MCP-1, } \\
\text { and MMP-2 }\end{array}$ & $\begin{array}{l}\text { Adiponectin level increased } \\
54 \% \text { after AT while } \\
\text { decreased by } 13 \% \text { after ART } \\
\text { MMP-2, TNF- } \alpha \text {, and } \\
\text { MCP-1 levels decreased in } \\
\text { AT while increased in ART } \\
\text { group }\end{array}$ \\
\hline 180 & $\begin{array}{l}23 \text { obese postmenopausal } \\
\text { women underwent resistance } \\
\text { exercise training or social } \\
\text { interaction intervention }\end{array}$ & $\begin{array}{l}3 \text { sets, } 10 \text { exercises, } 3 \times \text { per } \\
\text { week, } 8-12 \text { repetition } \\
\text { maximum }\end{array}$ & $\begin{array}{l}\text { IL-6, leptin, CRP, TNF- } \alpha \text {, } \\
\text { adiponectin, mRNA } \\
\text { expression of TLR } 4 \text {, and } \\
\text { MC1R. }\end{array}$ & $\begin{array}{l}\text { TNF- } \alpha \text {, CRP, and leptin } \\
\text { reduced in exercise group } \\
\text { without any change in body } \\
\text { composition }\end{array}$ \\
\hline
\end{tabular}

ALT: alanine aminotransferase; BMI: body mass index; CRP: C reactive protein; FBS: fasting blood sugar; GLUT4: glucose transporter 4; HDL: high density lipoprotein; IFN- $\gamma$ : interferon-gamma; MCP-1: monocyte chemoattractant protein-1; MC1R: melanocortin 1 receptor; MMP-2: matrix metalloproteinase-2; TG: triglyceride; TC: total cholesterol; TLR4: toll-like receptor 4. 
TABLE 5: Summary of selected clinical trials in which IL-6 level has been measured as a clinical outcome before and after exercise.

\begin{tabular}{|c|c|c|c|c|}
\hline Number & Subjects & Exercise intensity & Measured parameters & Results \\
\hline 181 & $\begin{array}{l}24 \text { insulin resistant } \\
\text { obese individuals }\end{array}$ & $\begin{array}{l}\text { Six months of moderate intensity } \\
\text { exercise plus hypocaloric diet }\end{array}$ & $\begin{array}{l}\text { IL-6, leptin, adiponectin, resistin, } \\
\text { TNF- } \alpha \text {, hsCRP, and insulin } \\
\text { sensitivity }\end{array}$ & $\begin{array}{l}\text { Plasma leptin and IL- } 6 \\
\text { decreased. TNF- } \alpha \text { tended to } \\
\text { decrease. Adiponectin increased } \\
\text { in diabetics }\end{array}$ \\
\hline 182 & $\begin{array}{l}56 \text { obese women and } \\
40 \text { age-matched } \\
\text { normal weight }\end{array}$ & $\begin{array}{l}\text { One year of increased physical } \\
\text { activity (at least } 1 \mathrm{~h} \text { walk } \\
3 \text { times/wk) plus energy } \\
\text { restricted diet }\end{array}$ & $\begin{array}{l}\text { Proinflammatory cytokines } \\
\text { including TNF- } \alpha \text {, IL-6, } \\
\text { P-selectin, VCAM-1, ICAM-1 } \\
\text { plus glucose, and lipid profile }\end{array}$ & $\begin{array}{l}\text { Proinflammatory cytokines were } \\
\text { higher in obese individuals } \\
\text { Weight reduction was associated } \\
\text { with decreased levels of IL- } 6 \text { and } \\
\text { TNF- } \alpha\end{array}$ \\
\hline 183 & $\begin{array}{l}15 \text { athletes } \\
\text { participants in an } \\
\text { ultradistance foot race }\end{array}$ & 246 Km Spartathlon & $\begin{array}{l}\text { IL-6, CRP, SAA, free plasma } \\
\text { DNA, and lipid profile }\end{array}$ & $\begin{array}{l}\text { IL-6 ( } 8000 \text { fold), CRP, SAA, and } \\
\text { free plasma DNA levels increased } \\
\text { at the end of this acute exercise }\end{array}$ \\
\hline 184 & $\begin{array}{l}49 \text { white obese school } \\
\text { aged children }\end{array}$ & $\begin{array}{l}\text { A combined protocol of energy } \\
\text { restriction and increased physical } \\
\text { activity for } 3 \text { weeks }\end{array}$ & $\begin{array}{l}\text { Indexes of obesity, IL-6, leptin, } \\
\text { estradiol, systolic and diastolic } \\
\text { BP, and HR }\end{array}$ & $\begin{array}{l}\text { All determined parameters } \\
\text { decreased significantly during } \\
\text { 3-week program }\end{array}$ \\
\hline 185 & $\begin{array}{l}17 \text { healthy young } \\
\text { women (YW) and } 8 \\
\text { postmenopausal } \\
\text { women (PMW) }\end{array}$ & $\begin{array}{l}\text { Five sets of six maximal eccentric } \\
\text { actions of the elbow flexors }\end{array}$ & $\begin{array}{l}\text { CK, IL-6, IL-10, TNF- } \alpha \text {, and } \\
\text { PGE2 }\end{array}$ & $\begin{array}{l}\text { For YW, IL- } 6 \text { and IL- } 10 \text { values } \\
\text { increased } 72 \mathrm{~h} \text { after eccentric } \\
\text { exercise }\end{array}$ \\
\hline 186 & 11 endurance athletes & $\begin{array}{l}\text { Two experimental trials } \\
\text { consisted of } 90 \text { min run at } 75 \% \text { of } \\
\mathrm{VO}_{2} \max \end{array}$ & $\begin{array}{l}\text { IL- } 6 \text {, free } \mathrm{Hb} \text {, haptoglobin, } \\
\text { hepcidin, and iron parameters }\end{array}$ & $\begin{array}{l}\text { Serum iron and IL- } 6 \text { significantly } \\
\text { increased after exercise }\end{array}$ \\
\hline 187 & $\begin{array}{l}60 \text { overweight/obese } \\
\text { diabetic patient } \\
\text { randomized to } \\
\text { exercise or control } \\
\text { groups }\end{array}$ & $\begin{array}{l}\text { 16-week aerobic exercise training } \\
\text { consisting of four } 45-60 \text { min } \\
\text { sessions/week }\left(50-60 \% \text { of } \mathrm{VO}_{2}\right. \\
\max )\end{array}$ & $\begin{array}{l}\text { Insulin resistance, plasma levels } \\
\text { of resistin, IL-6, FBS, and lipid } \\
\text { profile }\end{array}$ & $\begin{array}{l}\text { Exercise training decreased both } \\
\text { plasma IL- } 6 \text { and IL-18 }\end{array}$ \\
\hline
\end{tabular}

BP: blood pressure; FBS: fasting blood sugar; Hb: hemoglobin; HR: heart rate; hs-CRP: high sensitivity C reactive protein; ICAM-1: intercellular adhesion molecule-1; PGE2: prostaglandin E2; SAA: serum amyloid A; VCAM-1: vascular cell adhesion molecule.

metabolism and insulin sensitivity. On the other hand, as a muscle-secreted IL-6 myokine, it enhances glucose disposal and lipolysis and mediates the beneficial effects of physical activity. Another theory for explaining the increased amounts of IL- 6 in obesity and insulin resistance states is that elevated levels of IL-6 are a secondary defense response to higher amounts of TNF- $\alpha$. In other words, TNF- $\alpha$, as an important pathophysiological culprit in obesity, stimulates IL- 6 release. Alternatively, increased amounts of IL- 6 may represent a compensatory mechanism in insulin resistance conditions for maintaining glucose homeostasis. Furthermore, increased levels of IL- 6 may be a response to impaired IL-6 signaling [147], which is poorly defined in many clinical studies of obesity, insulin resistance, and diabetes.

2.8. Effect of Exercise on IL-6 Level. Interleukin-6 (IL-6) is the first cytokine to be released into the circulation during exercise, and its levels increase in an exponential fashion in response to physical exertion [148]. Exercise-induced increases in plasma IL-6 correlate with the muscle mass involved in exercise activity and also with the mode, duration, and, especially, the intensity of exercise [149]. The infusion of recombinant human IL-6 (rhIL-6) into human subjects simulates the exercise induced IL- 6 response in the prevention of endotoxin-induced increase in plasma TNF- $\alpha$ [150]. IL-6 inhibition of LPS-induced TNF- $\alpha$ production has also been shown in cultured human monocytes and IL-6 deficient knockout mice $[151,152]$. Furthermore, IL-6 stimulates the release of other anti-inflammatory cytokines including IL-10 and IL-1Ra [153]. These and other experiments suggest that the anti-inflammatory effects of exercise are partly mediated through increased levels of IL-6.

Focusing on the results of clinical trials that have measured IL-6 reveals the following generalities. First, the magnitude of IL- 6 increment is higher after moderate to severe exercise in untrained individuals. Exercise training decreases the magnitude of IL-6 response following strenuous activity. Second, exercise decreases blood levels of IL-6 in the metabolic syndrome and obese patients, while normal weight individuals experience increased levels of IL- 6 when it is released as a myokine. Genetic polymorphism is another confounding factor which might explain differences in exerciseinduced IL-6 variations [154]. Table 5 summarizes the results of some experiments in which IL-6 was part of laboratory outcomes in clinical studies.

\section{Conclusion}

In reviewing the information on the effects of exercise on adipokine levels (Figure 2), several drawbacks hinder lining a general conclusion. First, there is lack of unified standards in measuring the exercise intensity. These standards could 


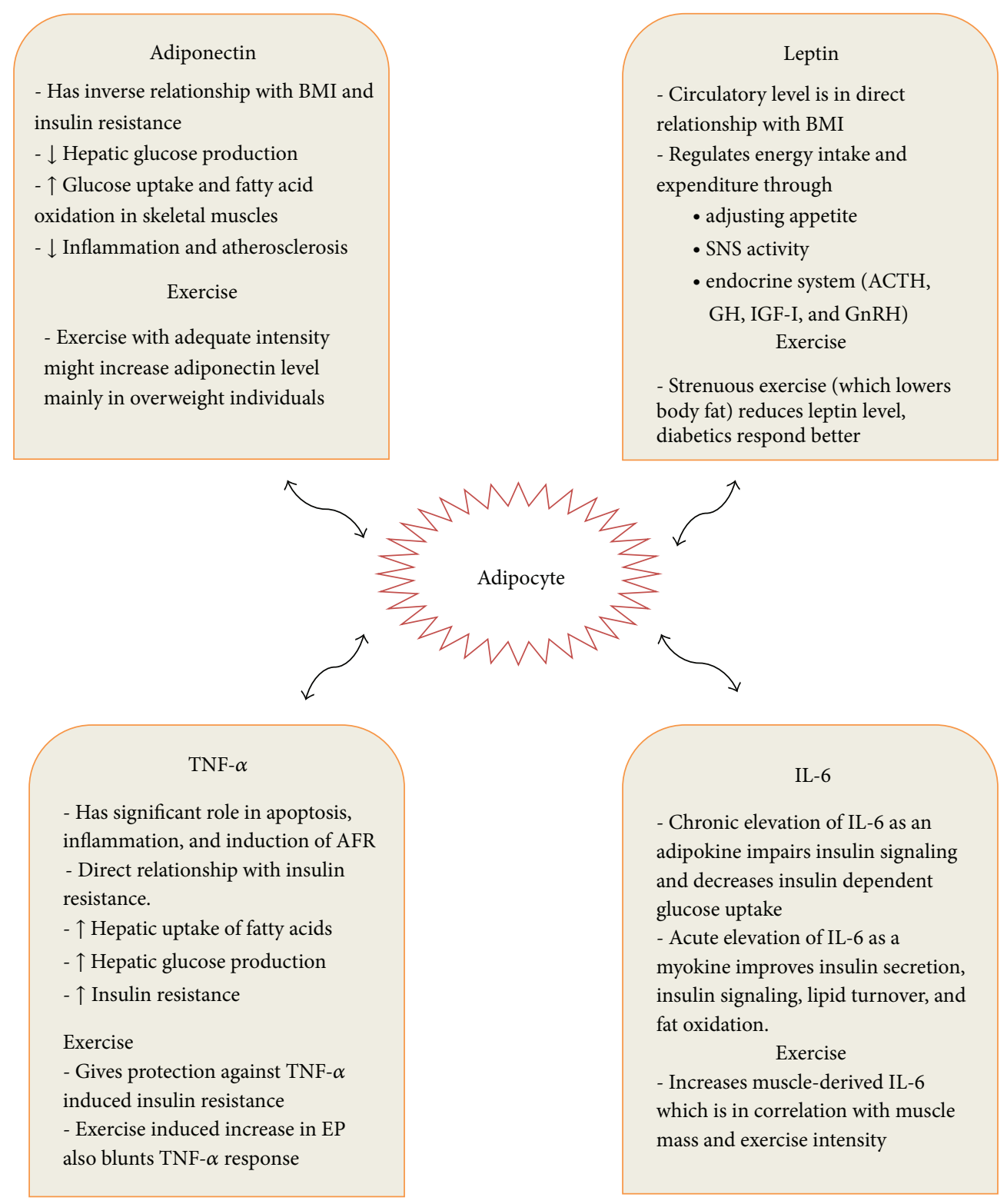

FIGURE 2: Selected physiologic effects of four adipokines and the effect of exercise on their blood levels.

be different among patients with various BMI levels as obese individuals may benefit more than normal-weight people from a certain level of physical activity. Exercise should exceed a defined level that is known to bring about physiologic changes. These thresholds have not been defined precisely in different groups of people. The in vivo interaction between different adipokines is another point which has mostly been ignored in isolated cytokines measurements. For instance, higher levels of adiponectin hinder the secretion of TNF- $\alpha$ and IL-6 [155], while TNF- $\alpha$ negatively affects adiponectin production and enhances IL-6 production [78]. There are also many other adipokines which yet have not been investigated in this context. Unraveling the complex physiology and relations between various adipokines can lead to a better understanding of sport physiology.

\section{Conflict of Interests}

The authors declare that there is no conflict of interests regarding the publication of this paper.

\section{References}

[1] T. Fujita, "Insulin resistance and salt-sensitive hypertension in metabolic syndrome," Nephrology Dialysis Transplantation, vol. 22, no. 11, pp. 3102-3107, 2007.

[2] T. Fujita, "Aldosterone in salt-sensitive hypertension and metabolic syndrome," Journal of Molecular Medicine, vol. 86, no. 6, pp. 729-734, 2008.

[3] American Diabetes Association, 2008, http://www.diabetes .org/diabetes-basics/diabetes-statistics. 
[4] Y.-W. Park, S. Zhu, L. Palaniappan, S. Heshka, M. R. Carnethon, and S. B. Heymsfield, "The metabolic syndrome: prevalence and associated risk factor findings in the US population from the Third National Health and Nutrition Examination Survey, 1988-1994," Archives of Internal Medicine, vol. 163, no. 4, pp. 427-436, 2003.

[5] I. D. Caterson, V. Hubbard, G. A. Bray et al., "Prevention conference VII: obesity, a worldwide epidemic related to heart disease and stroke: group III: worldwide comorbidities of obesity," Circulation, vol. 110, no. 18, pp. e476-e483, 2004.

[6] R. H. Eckel, S. M. Grundy, and P. Z. Zimmet, "The metabolic syndrome," The Lancet, vol. 365, no. 9468, pp. 1415-1428, 2005.

[7] A. Galassi, K. Reynolds, and J. He, "Metabolic syndrome and risk of cardiovascular disease: a meta-analysis," The American Journal of Medicine, vol. 119, no. 10, pp. 812-819, 2006.

[8] G. M. Reaven, "Role of insulin resistance in human disease," Diabetes, vol. 37, no. 12, pp. 1595-1607, 1988.

[9] G. M. Reaven, "Insulin resistance: the link between obesity and cardiovascular disease," Medical Clinics of North America, vol. 95, no. 5, pp. 875-892, 2011.

[10] T. You, B. J. Nicklas, J. Ding et al., "The metabolic syndrome is associated with circulating adipokines in older adults across a wide range of adiposity," Journals of Gerontology A, vol. 63, no. 4, pp. 414-419, 2008.

[11] A. M. W. Petersen and B. K. Pedersen, "The anti-inflammatory effect of exercise," Journal of Applied Physiology, vol. 98, no. 4, pp. 1154-1162, 2005.

[12] M. J. LaMonte, S. N. Blair, and T. S. Church, "Physical activity and diabetes prevention," Journal of Applied Physiology, vol. 99, pp. 1205-1213, 2005.

[13] H. Bruunsgaard, "Physical activity and modulation of systemic low-level inflammation," Journal of Leukocyte Biology, vol. 78, no. 4, pp. 819-835, 2005.

[14] A. I. Moldoveanu, R. J. Shephard, and P. N. Shek, "The cytokine response to physical activity and training," Sports Medicine, vol. 31, no. 2, pp. 115-144, 2001.

[15] C. Kasapis and P. D. Thompson, "The effects of physical activity on serum C-reactive protein and inflammatory markers: a systematic review," Journal of the American College of Cardiology, vol. 45, no. 10, pp. 1563-1569, 2005.

[16] T.-S. Tsao, H. E. Murrey, C. Hug, D. H. Lee, and H. F. Lodish, "Oligomerization state-dependent activation of NF- $\kappa \mathrm{B}$ signaling pathway by adipocyte complement-related protein of $30 \mathrm{kDa}$ (Acrp30)," Journal of Biological Chemistry, vol. 277, no. 33, pp. 29359-29362, 2002.

[17] U. B. Pajvani, X. Du, T. P. Combs et al., "Structure-function studies of the adipocyte-secreted hormone Acrp30/adiponectin: implications for metabolic regulation and bioactivity," Journal of Biological Chemistry, vol. 278, no. 11, pp. 9073-9085, 2003.

[18] S. Suzuki, E. M. Wilson-Kubalek, D. Wert, T.-S. Tsao, and D. H. Lee, "The oligomeric structure of high molecular weight adiponectin," FEBS Letters, vol. 581, no. 5, pp. 809-814, 2007.

[19] U. B. Pajvani, M. Hawkins, T. P. Combs et al., "Complex distribution, not absolute amount of adiponectin, correlates with thiazolidinedione-mediated improvement in insulin sensitivity," Journal of Biological Chemistry, vol. 279, no. 13, pp. 1215212162, 2004.

[20] D. K. Oh, T. Ciaraldi, and R. R. Henry, "Adiponectin in health and disease," Diabetes, Obesity and Metabolism, vol. 9, no. 3, pp. 282-289, 2007.
[21] S. Rizza, F. Gigli, A. Galli et al., "Adiponectin isoforms in elderly patients with or without coronary artery disease," Journal of the American Geriatrics Society, vol. 58, no. 4, pp. 702-706, 2010.

[22] P. Almeda-Valdes, D. Cuevas-Ramos, R. Mehta et al., "Total and high molecular weight adiponectin have similar utility for the identification of insulin resistance," Cardiovascular Diabetology, vol. 9, article 26, 2010.

[23] S. Mazaki-Tovi, H. Kanety, and E. Sivan, "Adiponectin and human pregnancy," Current Diabetes Reports, vol. 5, no. 4, pp. 278-281, 2005.

[24] W.-S. Yang, W.-J. Lee, T. Funahashi et al., "Weight reduction increases plasma levels of an adipose-derived antiinflammatory protein, adiponectin," Journal of Clinical Endocrinology and Metabolism, vol. 86, no. 8, pp. 3815-3819, 2001.

[25] A. Mavri, P. Poredoš, D. Šuran, B. Gaborit, I. Juhan-Vague, and P. Poredoš, "Effect of diet-induced weight loss on endothelial dysfunction: early improvement after the first week of dieting," Heart and Vessels, vol. 26, no. 1, pp. 31-38, 2011.

[26] K. Ohashi, N. Ouchi, and Y. Matsuzawa, "Anti-inflammatory and anti-atherogenic properties of adiponectin," Biochimie, vol. 94, pp. 2137-2142, 2012.

[27] K. J. Mather, T. Funahashi, Y. Matsuzawa et al., "Adiponectin, change in adiponectin, and progression to diabetes in the diabetes prevention program," Diabetes, vol. 57 , no. 4 , pp. 980 986, 2008.

[28] M. B. Snijder, R. J. Heine, J. C. Seidell et al., "Associations of adiponectin levels with incident impaired glucose metabolism and type 2 diabetes in older men and women the hoorn study," Diabetes Care, vol. 29, no. 11, pp. 2498-2503, 2006.

[29] J. Krakoff, T. Funahashi, C. D. A. Stehouwer et al., "Inflammatory markers, adiponectin, and risk of type 2 diabetes in the Pima Indian," Diabetes Care, vol. 26, no. 6, pp. 1745-1751, 2003.

[30] A. H. Berg, T. P. Combs, X. Du, M. Brownlee, and P. E. Scherer, "The adipocyte-secreted protein Acrp30 enhances hepatic insulin action," Nature Medicine, vol. 7, no. 8, pp. 947953, 2001.

[31] T. Yamauchi, J. Kamon, Y. Minokoshi et al., "Adiponectin stimulates glucose utilization and fatty-acid oxidation by activating AMP-activated protein kinase," Nature Medicine, vol. 8, no. 11, pp. 1288-1295, 2002.

[32] M. Okamoto, M. Ohara-Imaizumi, N. Kubota et al., "Adiponectin induces insulin secretion in vitro and in vivo at a low glucose concentration," Diabetologia, vol. 51, no. 5, pp. 827-835, 2008.

[33] G. Musso, R. Gambino, G. Biroli et al., "Hypoadiponectinemia predicts the severity of hepatic fibrosis and pancreatic beta-cell dysfunction in nondiabetic nonobese patients with nonalcoholic steatohepatitis," The American Journal of Gastroenterology, vol. 100, no. 11, pp. 2438-2446, 2005.

[34] R. Retnakaran, A. J. G. Hanley, N. Raif et al., "Adiponectin and beta cell dysfunction in gestational diabetes: pathophysiological implications," Diabetologia, vol. 48, no. 5, pp. 993-1001, 2005.

[35] N. Ouchi, S. Kihara, Y. Arita et al., "Adiponectin, an adipocytederived plasma protein, inhibits endothelial NF- $\kappa$ B signaling through a cAMP-dependent pathway," Circulation, vol. 102, no. 11, pp. 1296-1301, 2000.

[36] T. Yokota, K. Oritani, I. Takahashi et al., "Adiponectin, a new member of the family of soluble defense collagens, negatively regulates the growth of myelomonocytic progenitors and the functions of macrophages," Blood, vol. 96, no. 5, pp. 1723-1732, 2000 . 
[37] Y. Okamoto, S. Kihara, N. Ouchi et al., "Adiponectin reduces atherosclerosis in apolipoprotein E-deficient mice," Circulation, vol. 106, no. 22, pp. 2767-2770, 2002.

[38] K. Shimada, T. Miyazaki, and H. Daida, "Adiponectin and atherosclerotic disease," Clinica Chimica Acta, vol. 344, no. 1-2, pp. 1-12, 2004.

[39] T. Yamauchi, J. Kamon, H. Waki et al., "Globular adiponectin protected ob/ob mice from diabetes and ApoE-deficient mice from atherosclerosis," Journal of Biological Chemistry, vol. 278, no. 4, pp. 2461-2468, 2003.

[40] A. R. Nawrocki, M. W. Rajala, E. Tomas et al., "Mice lacking adiponectin show decreased hepatic insulin sensitivity and reduced responsiveness to peroxisome proliferator-activated receptor $\gamma$ agonists," Journal of Biological Chemistry, vol. 281, no. 5, pp. 2654-2660, 2006.

[41] J. Fruebis, T.-S. Tsao, S. Javorschi et al., "Proteolytic cleavage product of $30-\mathrm{kDa}$ adipocyte complement-related protein increases fatty acid oxidation in muscle and causes weight loss in mice," Proceedings of the National Academy of Sciences of the United States of America, vol. 98, no. 4, pp. 2005-2010, 2001.

[42] T. Yamauchi, Y. Nio, T. Maki et al., "Targeted disruption of AdipoR1 and AdipoR2 causes abrogation of adiponectin binding and metabolic actions," Nature Medicine, vol. 13, no. 3, pp. 332-339, 2007.

[43] K. Hara, P. Boutin, Y. Mori et al., "Genetic variation in the gene encoding adiponectin is associated with an increased risk of type 2 diabetes in the Japanese population," Diabetes, vol. 51, pp. 536-540, 2002.

[44] A. H. Kissebah, G. E. Sonnenberg, J. Myklebust et al., "Quantitative trait loci on chromosomes 3 and 17 influence phenotypes of the metabolic syndrome," Proceedings of the National Academy of Sciences of the United States of America, vol. 97, no. 26, pp. 14478-14483, 2000.

[45] H. Kondo, L. Shimomura, Y. Matsukawa et al., "Association of adiponectin mutation with type 2 diabetes: a candidate gene for the insulin resistance syndrome," Diabetes, vol. 51, no. 7, pp. 2325-2328, 2002.

[46] M. Stumvoll, O. Tschritter, A. Fritsche et al., "Association of the T-G polymorphism in adiponectin (Exon 2) with obesity and insulin sensitivity: interaction with family history of type 2 diabetes," Diabetes, vol. 51, no. 1, pp. 37-41, 2002.

[47] C. Menzaghi, T. Ercolino, R. D. Paola et al., "A haplotype at the adiponectin locus is associated with obesity and other features of the insulin resistance syndrome," Diabetes, vol. 51, no. 7, pp. 2306-2312, 2002.

[48] M. A. Ferguson, L. J. White, S. McCoy, H.-W. Kim, T. Petty, and J. Wilsey, "Plasma adiponectin response to acute exercise in healthy subjects," European Journal of Applied Physiology, vol. 91, no. 2-3, pp. 324-329, 2004.

[49] C. Punyadeera, A. H. G. Zorenc, R. Koopman et al., "The effects of exercise and adipose tissue lipolysis on plasma adiponectin concentration and adiponectin receptor expression in human skeletal muscle," European Journal of Endocrinology, vol. 152, no. 3, pp. 427-436, 2005.

[50] T. Bobbert, U. Wegewitz, L. Brechtel et al., "Adiponectin oligomers in human serum during acute and chronic exercise: relation to lipid metabolism and insulin sensitivity," International Journal of Sports Medicine, vol. 28, no. 1, pp. 1-8, 2007.

[51] R. R. Kraemer and V. D. Castracane, "Exercise and humoral mediators of peripheral energy balance: ghrelin and adiponectin," Experimental Biology and Medicine, vol. 232, no. 2, pp. 184-194, 2007.
[52] A. Z. Jamurtas, V. Theocharis, G. Koukoulis et al., "The effects of acute exercise on serum adiponectin and resistin levels and their relation to insulin sensitivity in overweight males," European Journal of Applied Physiology, vol. 97, no. 1, pp. 122-126, 2006.

[53] S. Numao, Y. Katayama, Y. Hayashi, T. Matsuo, and K. Tanaka, "Influence of acute aerobic exercise on adiponectin oligomer concentrations in middle-aged abdominally obese men," Metabolism, vol. 60, no. 2, pp. 186-194, 2011.

[54] T. J. Saunders, A. Palombella, K. A. McGuire, P. M. Janiszewski, J. P. Després, and R. Ross, "Acute exercise increases adiponectin levels in abdominally obese men," Nutrition and Metabolism, vol. 2012, Article ID 148729, 6 pages, 2012.

[55] R. V. Considine, M. K. Sinha, M. L. Heiman et al., "Serum immunoreactive-leptin concentrations in normal-weight and obese humans," The New England Journal of Medicine, vol. 334, no. 5, pp. 292-295, 1996.

[56] S. Margetic, C. Gazzola, G. G. Pegg, and R. A. Hill, "Leptin: a review of its peripheral actions and interactions," International Journal of Obesity, vol. 26, no. 11, pp. 1407-1433, 2002.

[57] G. Matarese, S. Moschos, and C. S. Mantzoros, "Leptin in immunology," Journal of Immunology, vol. 174, no. 6, pp. 31373142, 2005.

[58] A. M. Brennan and C. S. Mantzoros, "Drug insight: the role of leptin in human physiology and pathophysiology: emerging clinical applications," Nature Clinical Practice Endocrinology and Metabolism, vol. 2, no. 6, pp. 318-327, 2006.

[59] H. Ge, L. Huang, T. Pourbahrami, and C. Li, "Generation of soluble leptin receptor by ectodomain shedding of membranespanning receptors in vitro and in vivo," Journal of Biological Chemistry, vol. 277, no. 48, pp. 45898-45903, 2002.

[60] S. M. Hileman, D. D. Pierroz, H. Masuzaki et al., "Characterizaton of short isoforms of the leptin receptor in rat cerebral microvessels and of brain uptake of leptin in mouse models of obesity," Endocrinology, vol. 143, no. 3, pp. 775-783, 2002.

[61] S. H. Bates and M. G. Myers Jr., "The role of leptin receptor signaling in feeding and neuroendocrine function," Trends in Endocrinology and Metabolism, vol. 14, no. 10, pp. 447-452, 2003.

[62] Q. Gao and T. L. Horvath, "Cross-talk between estrogen and leptin signaling in the hypothalamus," The American Journal of Physiology, vol. 294, no. 5, pp. E817-E826, 2008.

[63] R. Yang and L. A. Barouch, "Leptin signaling and obesity: cardiovascular consequences," Circulation Research, vol. 101, no. 6, pp. 545-559, 2007.

[64] S. H. Bates and M. G. Myers, "The role of leptin-STAT3 signaling in neuroendocrine function: an integrative perspective," Journal of Molecular Medicine, vol. 82, no. 1, pp. 12-20, 2004.

[65] C. Kloek, A. K. Haq, S. L. Dunn, H. J. Lavery, A. S. Banks, and M. G. Myers Jr., "Regulation of Jak kinases by intracellular leptin receptor sequences," Journal of Biological Chemistry, vol. 277, no. 44, pp. 41547-41555, 2002.

[66] K. D. Niswender, B. Gallis, J. E. Blevins, M. A. Corson, M. W. Schwartz, and D. G. Baskin, "Immunocytochemical detection of phosphatidylinositol 3-kinase activation by insulin and leptin," Journal of Histochemistry and Cytochemistry, vol. 51, no. 3, pp. 275-283, 2003.

[67] C. S. Mantzoros, F. Magkos, M. Brinkoetter et al., "Leptin in human physiology and pathophysiology," The American Journal of Physiology, vol. 301, no. 4, pp. E567-E584, 2011.

[68] J. L. Chan, K. Heist, A. M. DePaoli, J. D. Veldhuis, and C. S. Mantzoros, "The role of falling leptin levels in the neuroendocrine and metabolic adaptation to short-term starvation in 
healthy men," Journal of Clinical Investigation, vol. 111, no. 9, pp. 1409-1421, 2003.

[69] M. Rosenbaum, R. Goldsmith, D. Bloomfield et al., "Low-dose leptin reverses skeletal muscle, autonomic, and neuroendocrine adaptations to maintenance of reduced weight," Journal of Clinical Investigation, vol. 115, no. 12, pp. 3579-3586, 2005.

[70] J. L. Chan and C. S. Mantzoros, "Leptin and the hypothalamicpituitary regulation of the gonadotropin-gonadal axis," Pituitary, vol. 4, no. 1-2, pp. 87-92, 2001.

[71] K. K. Miller, M. S. Parulekar, E. Schoenfeld et al., "Decreased leptin levels in normal weight women with hypothalamic amenorrhea: the effects of body composition and nutritional intake," Journal of Clinical Endocrinology and Metabolism, vol. 83, no. 7, pp. 2309-2312, 1998.

[72] C. S. Mantzoros, "The role of leptin and hypothalamic neuropeptides in energy homeostasis: update on leptin in obesity," Growth Hormone and IGF Research, vol. 11, no. 1, pp. S85-S89, 2001.

[73] S. Moschos, J. L. Chan, and C. S. Mantzoros, "Leptin and reproduction: a review," Fertility and Sterility, vol. 77, no. 3, pp. 433-444, 2002.

[74] M. G. Myers, M. A. Cowley, and H. Münzberg, "Mechanisms of leptin action and leptin resistance," Annual Review of Physiology, vol. 70, pp. 537-556, 2008.

[75] K. El-Haschimi, D. D. Pierroz, S. M. Hileman, C. Bjørbæk, and J. S. Flier, "Two defects contribute to hypothalamic leptin resistance in mice with diet-induced obesity," Journal of Clinical Investigation, vol. 105, no. 12, pp. 1827-1832, 2000.

[76] H. Münzberg and M. G. Myers Jr., "Molecular and anatomical determinants of central leptin resistance," Nature Neuroscience, vol. 8, pp. 566-570, 2005.

[77] T. Fuentes, I. Ara, A. Guadalupe-Grau et al., "Leptin receptor $170 \mathrm{kDa}(\mathrm{OB}-\mathrm{R} 170)$ protein expression is reduced in obese human skeletal muscle: a potential mechanism of leptin resistance," Experimental Physiology, vol. 95, no. 1, pp. 160-171, 2010.

[78] L. E. Stefanyk and D. J. Dyck, "The interaction between adipokines, diet and exercise on muscle insulin sensitivity," Current Opinion in Clinical Nutrition and Metabolic Care, vol. 13, no. 3, pp. 255-259, 2010.

[79] S. B. Jorgensen, H. M. O’Neill, L. Sylow et al., "Deletion of skeletal muscle SOCS3 prevents insulin resistance in obesity," Diabetes, vol. 62, pp. 56-64, 2013.

[80] T. G. Kirchgessner, K. T. Uysal, S. M. Wiesbrock, M. W. Marino, and G. S. Hotamisligil, "Tumor necrosis factor- $\alpha$ contributes to obesity-related hyperleptinemia by regulating leptin release from adipocytes," Journal of Clinical Investigation, vol. 100, no. 11, pp. 2777-2782, 1997.

[81] C. S. Mantzoros, S. Moschos, I. Avramopoulos et al., "Leptin concentrations in relation to body mass index and the tumor necrosis factor- $\alpha$ system in humans," Journal of Clinical Endocrinology and Metabolism, vol. 82, no. 10, pp. 3408-3413, 1997.

[82] P. Trayhurn, M. E. A. Thomas, J. S. Duncan, S. Duncan, and D. Vernon Rayner, "Effects of fasting and refeeding on ob gene expression in white adipose tissue of lean and obese (ob/ob) mice," FEBS Letters, vol. 368, no. 3, pp. 488-490, 1995.

[83] R. Saladin, P. De Vos, M. Guerre-Millo et al., "Transient increase in obese gene expression after food intake or insulin administration," Nature, vol. 377, no. 6549, pp. 527-529, 1995.

[84] C. M. Halleux, I. Servais, B. A. Reul, R. Detry, and S. M. Brichard, "Multihormonal control of ob gene expression and leptin secretion from cultured human visceral adipose tissue: increased responsiveness to glucocorticoids in obesity," Journal of Clinical Endocrinology and Metabolism, vol. 83, no. 3, pp. 902910, 1998.

[85] R. R. Kraemer, H. Chu, and V. Daniel Castracane, "Leptin and exercise," Experimental Biology and Medicine, vol. 227, no. 9, pp. 701-708, 2002.

[86] A. Bouassida, K. Chamari, M. Zaouali, Y. Feki, A. Zbidi, and Z. Tabka, "Review on leptin and adiponectin responses and adaptations to acute and chronic exercise," British Journal of Sports Medicine, vol. 44, no. 9, pp. 620-630, 2010.

[87] M. Zaccaria, A. Ermolao, G. S. Roi, P. Englaro, G. Tegon, and M. Varnier, "Leptin reduction after endurance races differing in duration and energy expenditure," European Journal of Applied Physiology, vol. 87, no. 2, pp. 108-111, 2002.

[88] R. R. Kraemer, L. G. Johnson, R. Haltom et al., "Serum leptin concentrations in response to acute exercise in postmenopausal women with and without hormone replacement therapy," Proceedings of the Society for Experimental Biology and Medicine, vol. 221, no. 3, pp. 171-177, 1999.

[89] J. A. Kanaley, L. M. Fenicchia, C. S. Miller et al., "Resting leptin responses to acute and chronic resistance training in type 2 diabetic men and women," International Journal of Obesity, vol. 25, no. 10, pp. 1474-1480, 2001.

[90] N. D. Barwell, D. Malkova, C. N. Moran et al., "Exercise training has greater effects on insulin sensitivity in daughters of patients with type 2 diabetes than in women with no family history of diabetes," Diabetologia, vol. 51, no. 10, pp. 1912-1919, 2008.

[91] K. Clément, N. Viguerie, C. Poitou et al., "Weight loss regulates inflammation-related genes in white adipose tissue of obese subjects," The FASEB Journal, vol. 18, no. 14, pp. 1657-1669, 2004.

[92] G. S. Hotamisligil, N. S. Shargill, and B. M. Spiegelman, "Adipose expression of tumor necrosis factor- $\alpha$ : direct role in obesity-linked insulin resistance," Science, vol. 259, no. 5091, pp. 87-91, 1993.

[93] P. A. Kern, M. Saghizadeh, J. M. Ong, R. J. Bosch, R. Deem, and R. B. Simsolo, "The expression of tumor necrosis factor in human adipose tissue. Regulation by obesity, weight loss, and relationship to lipoprotein lipase," Journal of Clinical Investigation, vol. 95, no. 5, pp. 2111-2119, 1995.

[94] K. T. Uysal, S. M. Wiesbrock, M. W. Marino, and G. S. Hotamisligil, "Protection from obesity-induced insulin resistance in mice lacking TNF- $\alpha$ function," Nature, vol. 389, no. 6651, pp. 610-614, 1997.

[95] M.-F. Hivert, L. M. Sullivan, C. S. Fox et al., "Associations of adiponectin, resistin, and tumor necrosis factor- $\alpha$ with insulin resistance," Journal of Clinical Endocrinology and Metabolism, vol. 93, no. 8, pp. 3165-3172, 2008.

[96] Y. Mishima, A. Kuyama, A. Tada, K. Takahashi, T. Ishioka, and M. Kibata, "Relationship between serum tumor necrosis factor$\alpha$ and insulin resistance in obese men with Type 2 diabetes mellitus," Diabetes Research and Clinical Practice, vol. 52, no. 2, pp. 119-123, 2001.

[97] G. Winkler, F. Salamon, G. Harmos et al., "Elevated serum tumor necrosis factor-alpha concentrations and bioactivity in Type 2 diabetics and patients with android type obesity," Diabetes Research and Clinical Practice, vol. 42, no. 3, pp. 169174, 1998.

[98] M. Saghizadeh, J. M. Ong, W. T. Garvey, R. R. Henry, and P. A. Kern, "The expression of TNF $\alpha$ by human muscle: relationship to insulin resistance," Journal of Clinical Investigation, vol. 97, no. 4, pp. 1111-1116, 1996. 
[99] A. M. Diehl, "Tumor necrosis factor and its potential role in insulin resistance and nonalcoholic fatty liver disease," Clinics in Liver Disease, vol. 8, no. 3, pp. 619-638, 2004.

[100] K. T. Uysal, S. M. Wiesbrock, and G. S. Hotamisligil, "Functional analysis of tumor necrosis factor (TNF) receptors in TNF- $\alpha$ mediated insulin resistance in genetic obesity," Endocrinology, vol. 139, no. 12, pp. 4832-4838, 1998.

[101] A. Gastaldelli and G. Basta, "Ectopic fat and cardiovascular disease: what is the link?" Nutrition, Metabolism and Cardiovascular Diseases, vol. 20, no. 7, pp. 481-490, 2010.

[102] A. Katsuki, Y. Sumida, H. Urakawa et al., "Increased visceral fat and serum levels of triglyceride are associated with insulin resistance in Japanese metabolically obese, normal weight subjects with normal glucose tolerance," Diabetes Care, vol. 26, no. 8, pp. 2341-2344, 2003.

[103] I. Gabriely and N. Barzilai, "Surgical removal of visceral adipose tissue: effects on insulin action," Current Diabetes Reports, vol. 3, no. 3, pp. 201-206, 2003.

[104] B. L. Wajchenberg, "Subcutaneous and visceral adipose tissue: their relation to the metabolic syndrome," Endocrine Reviews, vol. 21, no. 6, pp. 697-738, 2000.

[105] M. M. Ibrahim, "Subcutaneous and visceral adipose tissue: structural and functional differences," Obesity Reviews, vol. 11, no. 1, pp. 11-18, 2010.

[106] G. N. Chaldakov, I. S. Stankulov, M. Hristova, and P. I. Ghenev, "Adipobiology of disease: adipokines and adipokine-targeted pharmacology," Current Pharmaceutical Design, vol. 9, no. 12, pp. 1023-1031, 2003.

[107] P. D. Berk, S. L. Zhou, M. Bradbury, D. Stump, C. L. Kiang, and L. M. Isola, "Regulated membrane transport of free fatty acids in adipocytes: role in obesity and non-insulin dependent diabetes mellitus," Transactions of the American Clinical and Climatological Association, vol. 108, pp. 26-43, 1996.

[108] C. R. Bruce and D. J. Dyck, "Cytokine regulation of skeletal muscle fatty acid metabolism: effect of interleukin- 6 and tumor necrosis factor- $\alpha$," The American Journal of Physiology, vol. 287, no. 4, pp. E616-E621, 2004.

[109] K. Schulze-Osthoff, A. C. Bakker, B. Vanhaesebroeck, R. Beyaert, W. A. Jacob, and W. Fiers, "Cytotoxic activity of tumor necrosis factor is mediated by early damage of mitochondrial functions. Evidence for the involvement of mitochondrial radical generation," Journal of Biological Chemistry, vol. 267, no. 8, pp. 5317-5323, 1992.

[110] J. C. Bournat and C. W. Brown, "Mitochondrial dysfunction in obesity," Current Opinion in Endocrinology, Diabetes and Obesity, vol. 17, no. 5, pp. 446-452, 2010.

[111] J. J. Lemasters, T. Qian, C. A. Bradham et al., "Mitochondrial dysfunction in the pathogenesis of necrotic and apoptotic cell death," Journal of Bioenergetics and Biomembranes, vol. 31, no. 4, pp. 305-319, 1999.

[112] S. Joshi-Barve, S. S. Barve, W. Butt, J. Klein, and C. J. McClain, "Inhibition of proteasome function leads to NF- $\kappa \mathrm{B}-$ independent IL-8 expression in human hepatocytes," Hepatology, vol. 38, no. 5, pp. 1178-1187, 2003.

[113] F. Mattusch, B. Dufaux, O. Heine, I. Mertens, and R. Rost, "Reduction of the plasma concentration of $\mathrm{C}$-reactive protein following nine months of endurance training," International Journal of Sports Medicine, vol. 21, no. 1, pp. 21-24, 2000.

[114] A. Festa, R. D’Agostino Jr., G. Howard, L. Mykkänen, R. P. Tracy, and S. M. Haffner, "Chronic subclinical inflammation as part of the insulin resistance syndrome: the insulin resistance atherosclerosis study (IRAS)," Circulation, vol. 102, no. 1, pp. 4247, 2000.

[115] E. P. Plaisance and P. W. Grandjean, "Physical activity and highsensitivity C-reactive protein," Sports Medicine, vol. 36, no. 5, pp. 443-458, 2006.

[116] K. E. Fallon, S. K. Fallon, and T. Boston, "The acute phase response and exercise: court and field sports," British Journal of Sports Medicine, vol. 35, no. 3, pp. 170-173, 2001.

[117] J. M. Fernández-Real and W. Ricart, "Insulin resistance and chronic cardiovascular inflammatory syndrome," Endocrine Reviews, vol. 24, no. 3, pp. 278-301, 2003.

[118] P. Welsh, E. Polisecki, M. Robertson et al., "Unraveling the directional link between adiposity and inflammation: a bidirectional mendelian randomization approach," Journal of Clinical Endocrinology and Metabolism, vol. 95, no. 1, pp. 93-99, 2010.

[119] W. Fiers, "Tumor necrosis factor: characterization at the molecular, cellular and in vivo level," FEBS Letters, vol. 285, no. 2, pp. 199-212, 1991.

[120] C. Keller, P. Keller, M. Giralt, J. Hidalgo, and B. K. Pedersen, "Exercise normalises overexpression of TNF- $\alpha$ in knockout mice," Biochemical and Biophysical Research Communications, vol. 321, no. 1, pp. 179-182, 2004.

[121] T. van der Poll, S. M. Coyle, K. Barbosa, C. C. Braxton, and S. F. Lowry, "Epinephrine inhibits tumor necrosis factor$\alpha$ and potentiates interleukin 10 production during human endotoxemia," Journal of Clinical Investigation, vol. 97, no. 3, pp. 713-719, 1996.

[122] B. J. Nicklas, T. You, and M. Pahor, "Behavioural treatments for chronic systemic inflammation: effects of dietary weight loss and exercise training," Canadian Medical Association Journal, vol. 172, no. 9, pp. 1199-1209, 2005.

[123] R. L. Bradley, J. Y. Jeon, F.-F. Liu, and E. Maratos-Flier, "Voluntary exercise improves insulin sensitivity and adipose tissue inflammation in diet-induced obese mice," The American Journal of Physiology, vol. 295, no. 3, pp. E586-E594, 2008.

[124] V. J. Vieira, R. J. Valentine, K. R. Wilund, N. Antao, T. Baynard, and J. A. Woods, "Effects of exercise and low-fat diet on adipose tissue inflammation and metabolic complications in obese mice," The American Journal of Physiology, vol. 296, no. 5, pp. E1164-E1171, 2009.

[125] T. Sakurai, T. Izawa, T. Kizaki et al., "Exercise training decreases expression of inflammation-related adipokines through reduction of oxidative stress in rat white adipose tissue," Biochemical and Biophysical Research Communications, vol. 379, no. 2, pp. 605-609, 2009.

[126] G. Lutoslawska, "Interleukin-6 as an adipokine and myokine: the regulatory role of cytokine in adipose tissue and skeletal muscle metabolism," Human Movement, vol. 13, pp. 372-379, 2012.

[127] B. Vozarova, C. Weyer, K. Hanson, P. A. Tataranni, C. Bogardus, and R. E. Pratley, "Circulating interleukin-6 in relation to adiposity, insulin action, and insulin secretion," Obesity Research, vol. 9, no. 7, pp. 414-417, 2001.

[128] F. Oberhauser, D. M. Schulte, M. Faust, H. Güdelhöfer, M. Hahn, and N. Müller, "Weight loss due to very low calorie diet differentially affects insulin sensitivity and interleukin-6 serum levels in non-diabetic obese human subjects," Hormone and Metabolic Research, vol. 44, pp. 465-470, 2012.

[129] A. R. Moschen, C. Molnar, S. Geiger et al., "Anti-inflammatory effects of excessive weight loss: potent suppression of adipose interleukin 6 and tumour necrosis factor a expression," Gut, vol. 59, no. 9, pp. 1259-1264, 2010. 
[130] J.-M. Fernandez-Real, M. Vayreda, C. Richart et al., "Circulating interleukin 6 levels, blood pressure, and insulin sensitivity in apparently healthy men and women," Journal of Clinical Endocrinology and Metabolism, vol. 86, no. 3, pp. 1154-1159, 2001.

[131] C. Tsigos, D. A. Papanicolaou, I. Kyrou, R. Defensor, C. S. Mitsiadis, and G. P. Chrousos, "Dose-dependent effects of recombinant human interleukin-6 on glucose regulation," Journal of Clinical Endocrinology and Metabolism, vol. 82, no. 12, pp. 4167-4170, 1997.

[132] V. Rotter, I. Nagaev, and U. Smith, "Interleukin-6 (IL-6) induces insulin resistance in 3T3-L1 adipocytes and is, like IL-8 and tumor necrosis factor- $\alpha$, overexpressed in human fat cells from insulin-resistant subjects," Journal of Biological Chemistry, vol. 278, no. 46, pp. 45777-45784, 2003.

[133] J. J. Senn, P. J. Klover, I. A. Nowak, and R. A. Mooney, "Interleukin-6 induces cellular insulin resistance in hepatocytes," Diabetes, vol. 51, no. 12, pp. 3391-3399, 2002.

[134] A. L. Carey, G. R. Steinberg, S. L. Macaulay et al., "Interleukin6 increases insulin-stimulated glucose disposal in humans and glucose uptake and fatty acid oxidation in vitro via AMPactivated protein kinase," Diabetes, vol. 55, no. 10, pp. 26882697, 2006.

[135] A. G. Holmes, J. L. Mesa, B. A. Neill et al., "Prolonged interleukin-6 administration enhances glucose tolerance and increases skeletal muscle PPAR $\alpha$ and UCP2 expression in rats," Journal of Endocrinology, vol. 198, no. 2, pp. 367-374, 2008.

[136] D. C. Nieman, J. M. Davis, D. A. Henson et al., "Carbohydrate ingestion influences skeletal muscle cytokine mRNA and plasma cytokine levels after a 3-h run," Journal of Applied Physiology, vol. 94, no. 5, pp. 1917-1925, 2003.

[137] C. Keller, A. Steensberg, H. Pilegaard et al., "Transcriptional activation of the IL-6 gene in human contracting skeletal muscle: influence of muscle glycogen content," The FASEB Journal, vol. 15, no. 14, pp. 2748-2750, 2001.

[138] C. Keller, A. Steensberg, A. K. Hansen, C. P. Fischer, P. Plomgaard, and B. K. Pedersen, "Effect of exercise, training, and glycogen availability on IL-6 receptor expression in human skeletal muscle," Journal of Applied Physiology, vol. 99, no. 6, pp. 2075-2079, 2005.

[139] H. Langberg, J. L. Olesen, C. Gemmer, and M. Kjær, "Substantial elevation of interleukin- 6 concentration in peritendinous tissue, in contrast to muscle, following prolonged exercise in humans," Journal of Physiology, vol. 542, no. 3, pp. 985-990, 2002.

[140] A. Steensberg, M. A. Febbraio, T. Osada et al., "Interleukin-6 production in contracting human skeletal muscle is influenced by pre-exercise muscle glycogen content," Journal of Physiology, vol. 537, no. 2, pp. 633-639, 2001.

[141] C. P. Fischer, "Interleukin-6 in acute exercise and training: what is the biological relevance?" Exercise Immunology Review, vol. 12, pp. 6-33, 2006.

[142] E. W. Petersen, A. L. Carey, M. Sacchetti et al., "Acute IL-6 treatment increases fatty acid turnover in elderly humans in vivo and in tissue culture in vitro," The American Journal of Physiology, vol. 288, no. 1, pp. E155-E162, 2005.

[143] V. Wallenius, K. Wallenius, B. Ahrén et al., "Interleukin-6deficient mice develop mature-onset obesity," Nature Medicine, vol. 8, no. 1, pp. 75-79, 2002.

[144] E. Wolsk, H. Mygind, T. S. Grøndahl, B. K. Pedersen, and G. van Hall, "IL-6 selectively stimulates fat metabolism in human skeletal muscle," The American Journal of Physiology, vol. 299, pp. E832-E840, 2010.

[145] G. van Hall, A. Steensberg, M. Sacchetti et al., "Interleukin6 stimulates lipolysis and fat oxidation in humans," Journal of Clinical Endocrinology and Metabolism, vol. 88, no. 7, pp. 30053010, 2003.

[146] H. Ellingsgaard, I. Hauselmann, B. Schuler et al., "Interleukin-6 enhances insulin secretion by increasing glucagon-like peptide1 secretion from L cells and alpha cells," Nature Medicine, vol. 17, no. 11, pp. 1481-1489, 2011.

[147] B. K. Pedersen and M. A. Febbraio, "Muscle as an endocrine organ: focus on muscle-derived interleukin-6," Physiological Reviews, vol. 88, pp. 1379-1406, 2008.

[148] N. Erdei, Z. Bagi, I. Édes, G. Kaley, and A. Koller, " $\mathrm{H}_{2} \mathrm{O}_{2}$ increases production of constrictor prostaglandins in smooth muscle leading to enhanced arteriolar tone in Type 2 diabetic mice," The American Journal of Physiology, vol. 292, no. 1, pp. H649-H656, 2007.

[149] B. K. Pedersen, M. A. Febbraio, and R. A. Mooney, "Interleukin6 does/does not have a beneficial role in insulin sensitivity and glucose homeostasis," Journal of Applied Physiology, vol. 102, no. 2, pp. 814-819, 2007.

[150] R. Starkie, S. R. Ostrowski, S. Jauffred, M. Febbraio, and B. K. Pedersen, "Exercise and IL-6 infusion inhibit endotoxininduced TNF-alpha production in humans," The FASEB Journal, vol. 17, no. 8, pp. 884-886, 2003.

[151] R. Schindler, J. Mancilla, S. Endres, R. Ghorbani, S. C. Clark, and C. A. Dinarello, "Correlations and interactions in the production of interleukin-6 (IL-6), IL-1, and tumor necrosis factor (TNF) in human blood mononuclear cells: IL-6 suppresses IL-1 and TNF," Blood, vol. 75, no. 1, pp. 40-47, 1990.

[152] H. Mizuhara, E. O’Neill, N. Seki et al., “T cell activationassociated hepatic injury: mediation by tumor necrosis factors and protection by interleukin 6," Journal of Experimental Medicine, vol. 179, no. 5, pp. 1529-1537, 1994.

[153] J. Szostak and P. Laurant, "The forgotten face of regular physical exercise: a 'natural' anti-atherogenic activity,' Clinical Science, vol. 121, no. 3, pp. 91-106, 2011.

[154] A. Oberbach, S. Lehmann, K. Kirsch et al., "Long-term exercise training decreases interleukin-6 (IL-6) serum levels in subjects with impaired glucose tolerance: effect of the $-174 \mathrm{G} / \mathrm{C}$ variant in IL-6 gene," European Journal of Endocrinology, vol. 159, no. 2, pp. 129-136, 2008.

[155] I. S. Lee, G. Shin, and R. Choue, "Shifts in diet from high fat to high carbohydrate improved levels of adipokines and proinflammatory cytokines in mice fed a high-fat diet," Endocrine Journal, vol. 57, no. 1, pp. 39-50, 2010. 


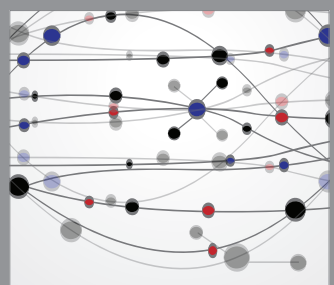

The Scientific World Journal
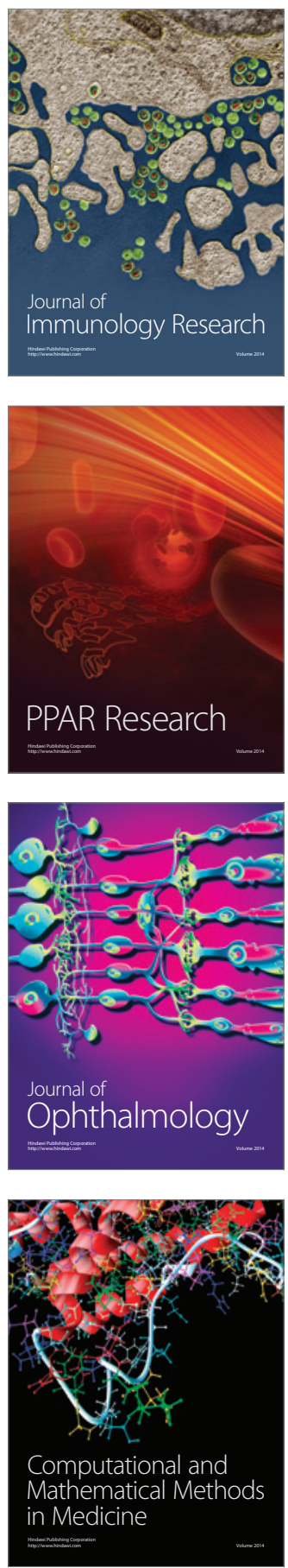

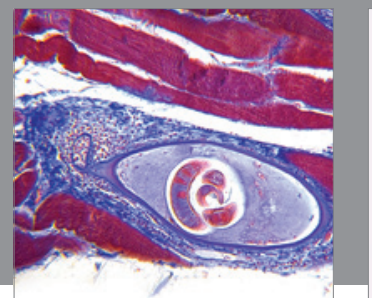

Gastroenterology

Research and Practice
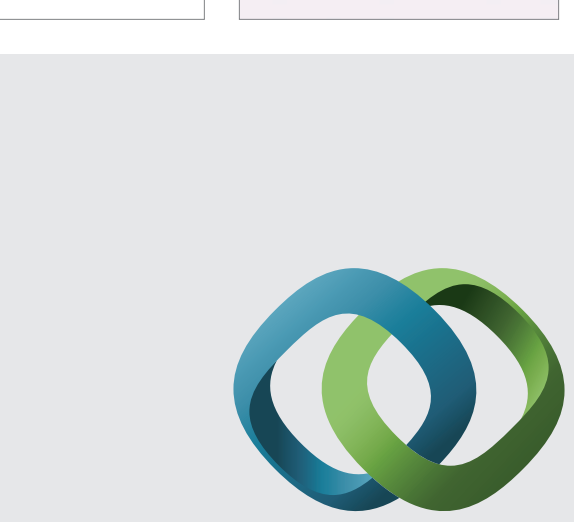

\section{Hindawi}

Submit your manuscripts at

http://www.hindawi.com
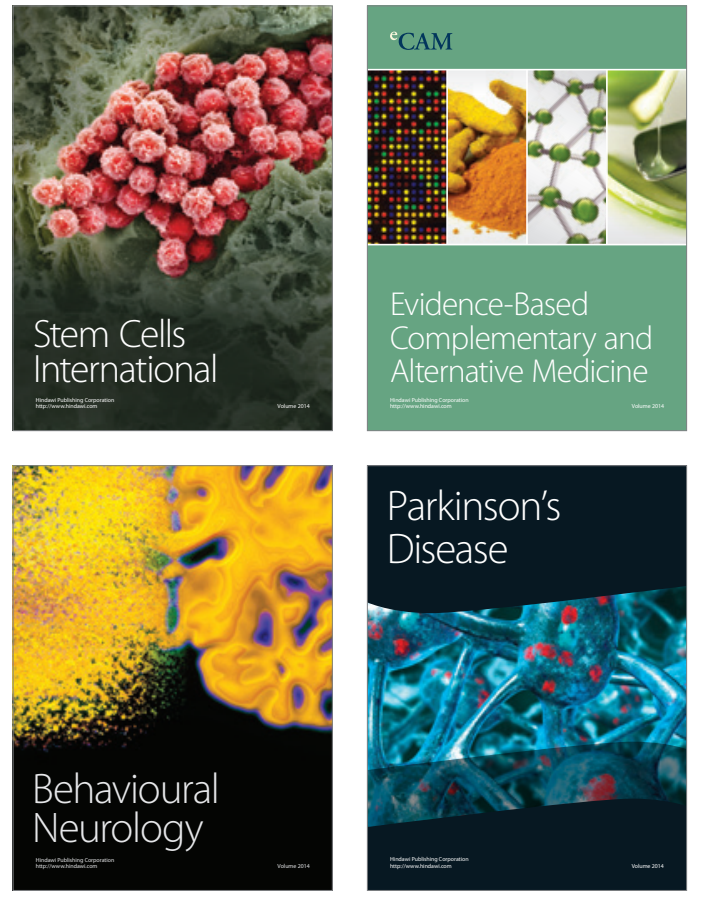
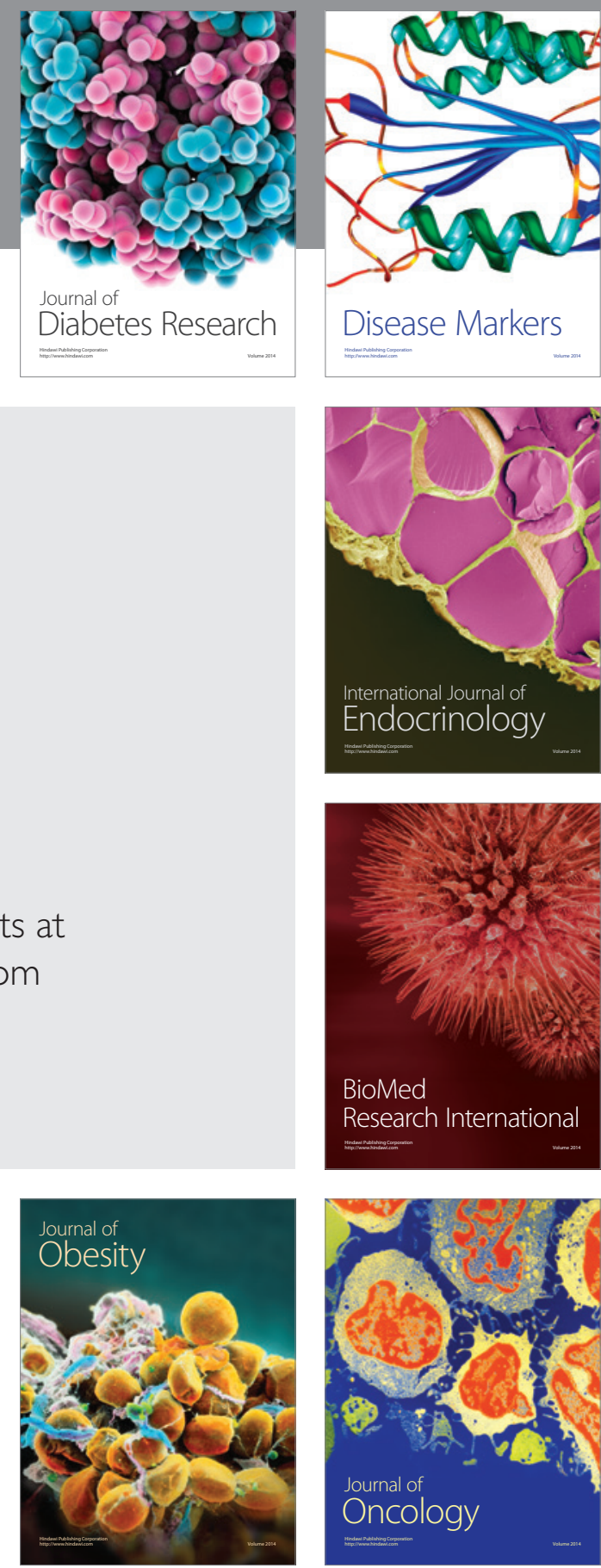

Disease Markers
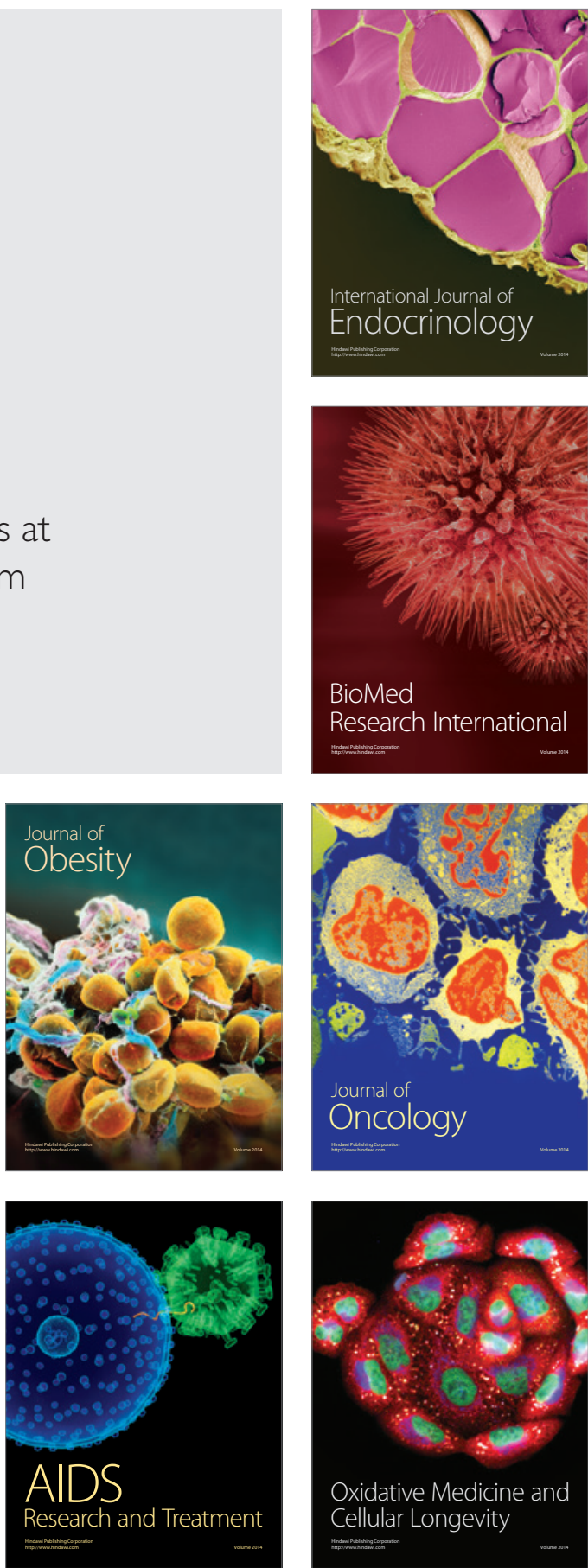